\title{
Treatment of Hypertension with Nutrition and Nutraceutical Supplements: Part 1
}

\author{
Mark C. Houston, MD, MS, MSC, FACP, FAHA, FASH, FACN, FAARM, DABC
}

\section{Introduction}

Cardiovascular disease (CVD) remains the leading cause of death in the United States. Hypertension is one of the top five risk factors for coronary heart disease (CHD) and CVD and remains the most common reason for visits to primary care physicians, with antihypertensive drugs costing > U.S.\$20 billion annually. ${ }^{1-19}$ There are $>100$ million people in the United States with hypertension based on new hypertension guidelines. ${ }^{19}$ In numerous clinical trials, pharmacotherapy will control blood pressure (BP) and reduce stroke, CHD, myocardial infarction (MI), congestive heart failure (CHF), and renal disease. ${ }^{16,17}$ However, some hypertensive patients either refuse to take drugs or prefer to treat with nutrition or nutritional supplements. ${ }^{1-20}$

Hypertension is a consequence of micro- and macronutrient insufficiencies, abnormal vascular biology, reduced bioavailability of nitric oxide (NO), and the three finite vascular responses to vascular injury: inflammation, oxidative stress, and vascular immune dysfunction with activation for cell-mediated immunity (see Fig. 1).$^{2-5,11-14}$ These abnormalities coexist and interact with genetics, epigenetics, nutrient-gene expression, and other environmental and lifestyle factors. ${ }^{2-5,11-14} \mathrm{Hy}-$ pertension is initially the expected and normal response to these infinite insults from the environment (including microbes, heavy metals, biochemical, biohumoral, and biomechanical issues, lipids, glucose, obesity, smoking, homocysteine, and many others) to the endothelium, but chronic dysregulation of this response associated with gene expression patterns leads to a complex series of vascular events in which the vascular system becomes an innocent bystander. ${ }^{2-5,11-14}$ Hypertension is one of several responses of the blood vessel to endothelial dysfunction (ED). Cardiac smooth-muscle and vascular dysfunction and abnormalities of both microvascular function and structure precede the development of hypertension by decades. This consequently leads to vascular and cardiac hypertrophy, remodeling, functional and structural network rarefaction, decreased vasodilatory reserve, altered media-to-lumen ratio, stiffness, loss of arterial elasticity, fibrosis, increased pulse pressure, elevated pulse wave velocity (PWV), and increased augmentation index (see Fig. 2). ${ }^{2-5,11-14}$ Significant functional and then structural microvascular impairment begins before elevations in $\mathrm{BP}$ in normotensive offspring of hypertensive parents. $^{2-5,11-14}$

As the BP increases, a bidirectional feedback occurs between the increased BP and the endothelial and vascular smooth-muscle dysfunction that exacerbates and perpetuates the cardiovascular functional and structural abnormalities. Macronutrients and micronutrients are crucial in the regulation of BP and subsequent cardiovascular target organ damage (TOD). ${ }^{2-5,11-14}$ Certain nutrient deficiencies are more common in patients with hypertension than in the general population. ${ }^{2-5,11-14}$ The appropriate measurement, interpretation, and treatment of these nutrient deficiencies may effectively lower BP and improve ED, vascular and cardiac functional and structural abnormalities, and cardiovascular events. ${ }^{2-5,11-14}$

This two-part article will primarily review the role of nutrition and selected nutraceutical supplements, minerals, vitamins, anti-inflammatory agents, natural immune modulators, and antioxidants in the treatment of hypertension.

\section{Epidemiology and Pathophysiology}

The human genome is $99.9 \%$ identical to our Paleolithic ancestors, but the ability of the genome to adapt to changes in modern nutrition and macronutrient and micronutrient intake explains some of the reasons for the increase in CVD (see Table 1). ${ }^{21}$ Derangements in vascular biology assumes a pivotal role in the initiation and perpetuation of hypertension. ${ }^{2-5,11-14}$ Reactive oxygen species (ROS) coupled with impaired oxidative defense, inflammatory mediators, vascular immune dysfunction, and loss of NO bioavailability contribute to hypertension through complex nutrient-gene interactions. ${ }^{2-5,11-14,22-32}$ The high sodium/potassium ratio of modern diets, the reduced intake of magnesium, fiber, protein, and omega-3 fatty acids (FA) with increased consumption of omega- 6 FA, saturated FA, and trans FA have contributed to hypertension. ${ }^{2-5,11-14,21}$ 


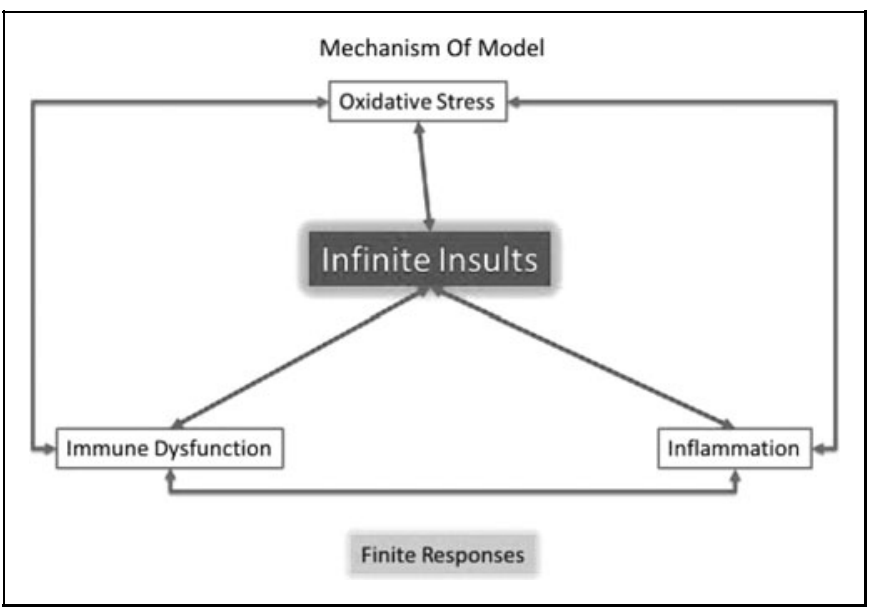

Figure 1. Finite responses to vascular injury. Infinite insults to the blood vessel result in only three finite responses of inflammation, oxidative stress, and vascular immune dysfunction. These finite responses result in endothelial dysfunction and vascular smoothmuscle dysfunction, which leads to clinical cardiovascular disease.

\section{Oxidative Stress, Inflammation, and Vascular Immune Dysfunction}

Oxidative stress is an imbalance of ROS with a decrease in antioxidant defenses that contributes to hypertension in humans based on genetics and environment. ${ }^{2-5,11-14,23-37}$ The predominant ROS produced is superoxide anion, which is generated by numerous cellular sources that uncouple endotheliumderived NO synthase (U-eNOS) and reduce NO bioavailability. This results in ED and increased BP. ${ }^{24,27}$ Antioxidant deficiency and excess free radical production have been implicated in human hypertension in epidemiologic, observational, and interventional studies. ${ }^{29-31}$ Free radicals degrade NO, influence eicosanoid metabolism, and increase catecholamine levels in serum and urine. ${ }^{2-5,11-14,24,26,27}$ The interrelations of neurohormonal systems, oxidative stress, and CVD is shown in Figure 3.

Acute and chronic inflammation with abnormal vascular immune responses and involvement of pattern recognition receptors (PRR) and Toll-like receptors (TLR) are involved in

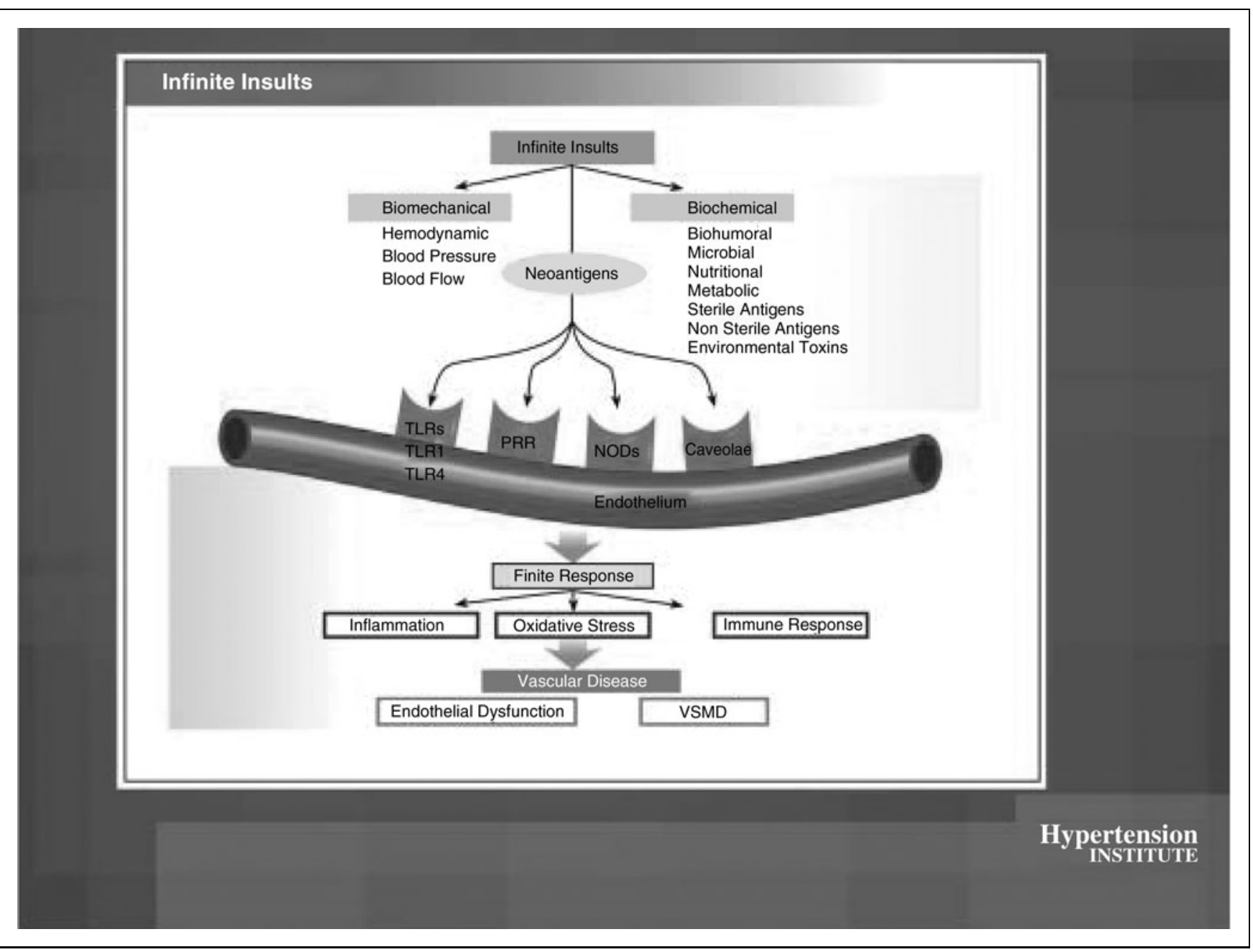

Figure 2. Infinite insults and the three finite vascular responses. Infinite insults and the three finite vascular responses of inflammation, oxidative stress, and vascular immune dysfunction lead to endothelial dysfunction and cardiac and vascular dysfunction. 


\begin{tabular}{|c|c|c|}
\hline \multicolumn{3}{|c|}{$\begin{array}{l}\text { Table 1. Contrasting the Intake of Nutrients Involved in Vascular Biology: } \\
\text { Evolutionary Nutritional Impositions }{ }^{\text {a }}\end{array}$} \\
\hline Nutrient & Paleolithic intake & Modern intake \\
\hline Potassium & $>10,000$ meq/day $(256 \mathrm{~g})$ & 150 meq/day $(6 \mathrm{~g})$ \\
\hline Sodium & $<50 \mathrm{mmol} /$ day $(1.2 \mathrm{~g})$ & $175 \mathrm{mmol} /$ day $(4 \mathrm{~g})$ \\
\hline Sodium/potassium ratio & $<0.13 /$ day & $>0.67 /$ day \\
\hline Fiber & $>100 \mathrm{~g} /$ day & $9 \mathrm{~g} /$ day \\
\hline Protein & $37 \%$ & $20 \%$ \\
\hline Carbohydrate & $41 \%$ & $40-50 \%$ \\
\hline Fat & $22 \%$ & $30-40 \%$ \\
\hline Polyunsaturated/saturated fat ratio & 1.4 & 0.4 \\
\hline
\end{tabular}

hypertension..$^{2-5,11-14,33-50}$ Low levels of interleukin 10 (IL10) and increased levels of high sensitivity C-reactive protein (hs-CRP), along with numerous inflammatory cytokines such as interleukins (IL-6, IL-1 $\beta$, IL-2, and IL-8), and tumor necrosis factor alpha (TNF- $\alpha)$ are excellent markers for hypertension and hypertensive-related TOD, such as CHD, CHF, and increased carotid intimal medial thickness (IMT). ${ }^{2-5,11-14,33-50}$ Elevated hs-CRP is both a risk marker and risk factor for hypertension and CVD. ${ }^{2,38,39}$ Increases in hs-CRP of $>3 \mu \mathrm{g} / \mathrm{mL}$ may increase BP rapidly in proportion to the serum hs-CRP level. $^{38,39}$ NO and eNOS are inhibited by CRP. ${ }^{38,39}$ The angiotensin 2 receptor (AT2R), which increases NO when stimulated, normally counterbalances AT1R, but it is downregulated or blocked by CRP. ${ }^{2,38,39}$ Angiotensin II (A-II) is inflammatory, atherogenic, increases oxidative stress and vascular immune dysfunction that involves $\mathrm{T}$ and $\mathrm{B}$ cells and the innate and adaptive immune system, and upregulates many of the cytokines. $2,44,49$

Innate and adaptive immune responses induce hypertension by numerous mechanisms that include A-II, antibodies to the AT1R, pro-inflammatory cytokine and chemokine production, PRR and TLR activation, central nervous system (CNS) stimulation, and renal damage. ${ }^{2-4,35,36,40-50}$ Monocytes cross the endothelial lining, invade the subintimal layer, and transform into macrophages. The macrophages, along with various $\mathrm{T}$-cell subtypes that regulate $\mathrm{BP}$, cause vascular damage and promote vascular immune dysfunction. ${ }^{41}$ A-II activates immune cells in the arterial system and also in the CNS. ${ }^{41,44,49}$ Activation of the AT1R and peroxisome proliferator-activated receptor gamma (PPAR- $\gamma$ ) receptors that are expressed on

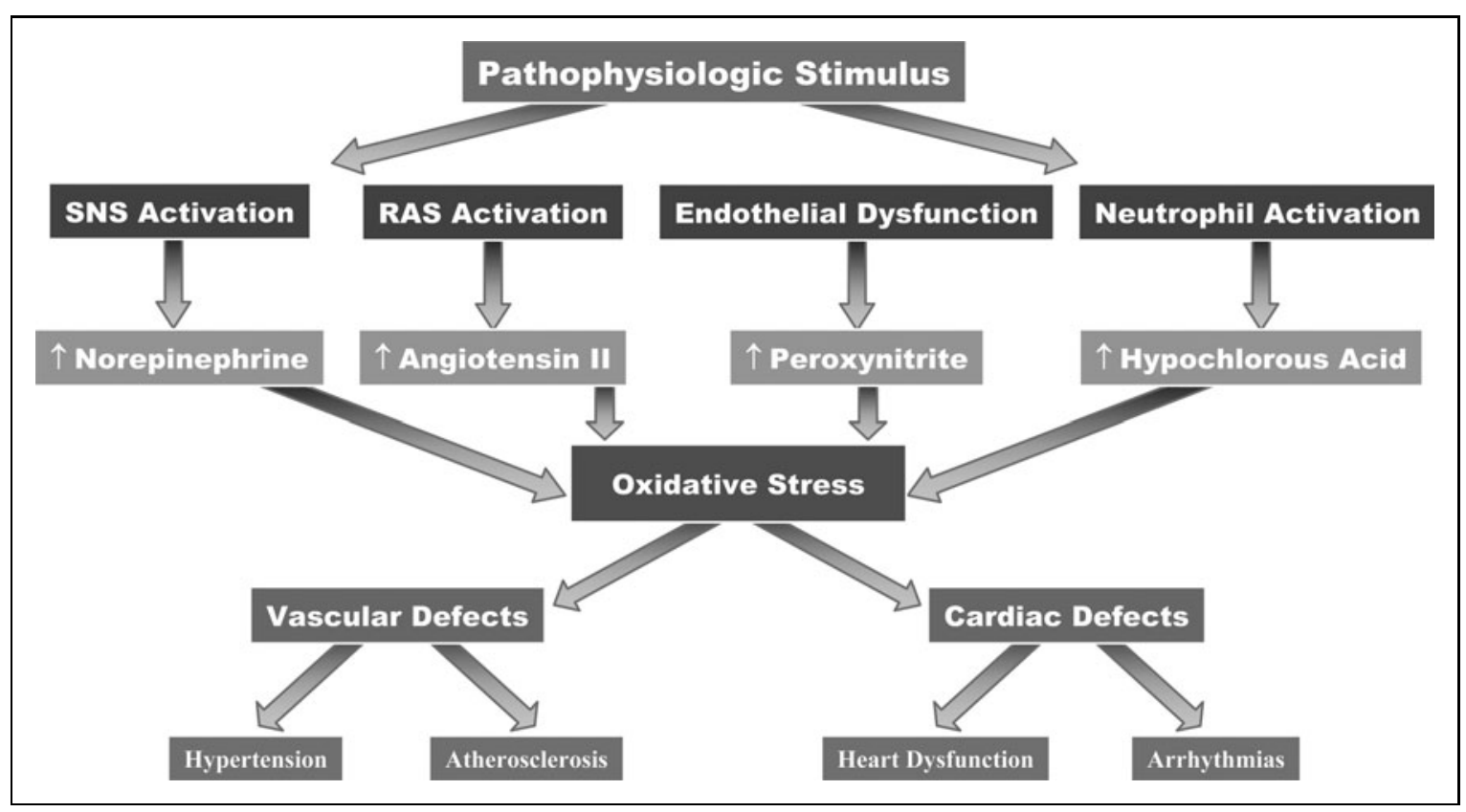

Figure 3. The neurohormonal and oxidative stress systems with interactions on cardiac and vascular muscle. The sympathetic nervous system and therein angiotensin system induce vasoconstriction, hypertension, and cardiovascular disease. Endothelial dysfunction increases oxidative stress from peroxynitrite, and activation of neutrophils increases oxidative stress from hypochlorous acid. The clinical consequences are hypertension, atherosclerosis, coronary heart disease (CHD), cardiovascular disease (CVD), congestive heart failure, and arrhythmias. 


\section{Vascular Disease is a Balance}

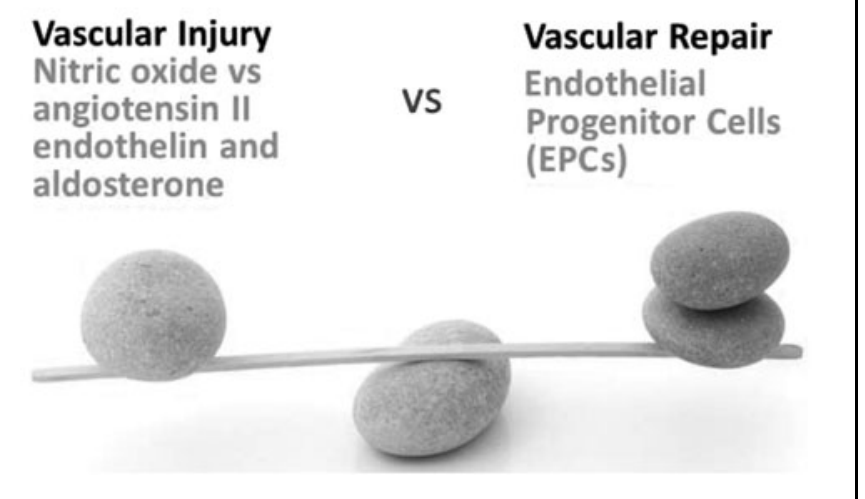

Figure 4. The balance of cardiovascular disease. Cardiovascular disease is a balance of vascular injury and vascular repair. Nitric oxide balances the injury induced by angiotensin II, endothelin, and aldosterone. The endothelial progenitor cells repair the endothelium. ${ }^{205,206}$

$\mathrm{CD} 4+\mathrm{T}$ lymphocytes release TNF- $\alpha$, interferons, and interleukins within the vascular wall. ${ }^{41,50}$ IL-17 produced by T-17 cells may play a pivotal role in the genesis and perpetuation of hypertension caused by A-II. ${ }^{41}$

\section{The Balance of Hypertension}

Hypertension is a balance of vascular damage and repair that is mediated through the three finite responses. Vasoconstric- tive and atherogenic hormones such as A-II, endothelin, and aldosterone are also involved in the hypertensive response with arterial constriction and sodium and water retention that increases the intravascular volume (see Figs. 4 and 5 )..$^{2-5,11-14}$ Vascular protection and repair is mediated by $\mathrm{NO}$ and bone marrow-derived endothelial progenitor cells (EPCs). ${ }^{2-5,11-14}$ The endothelium maintains communication and homeostasis between the circulating blood cells and the vascular media. It accomplishes this by modulation of the permeability, contractile state, proliferation, migratory response, and the redox state in the vascular media. It also modulates platelet function, coagulation, monocyte and leukocyte adhesion, inflammation, oxidative stress, and immune responses in the blood (see Figs. 6 and 7$)^{2-5,11-14}$

\section{Treatment of Hypertension with Nutritional Supplements}

A large number of nutraceutical supplements, antioxidants, vitamins, minerals, and natural compounds in food produce physiologic effects that mimic specific classes of antihypertensive medications, improve vascular biology, and decrease $\mathrm{BP}^{2-14}$ These natural compounds are pluripotent but may also be classified into the major antihypertensive drug groups, which assists clinicians in making a logical transition from a drug of a certain antihypertensive class to a supplement with a similar but broader mechanism of action. These classes include diuretics, beta blockers, central alpha agonists, calcium

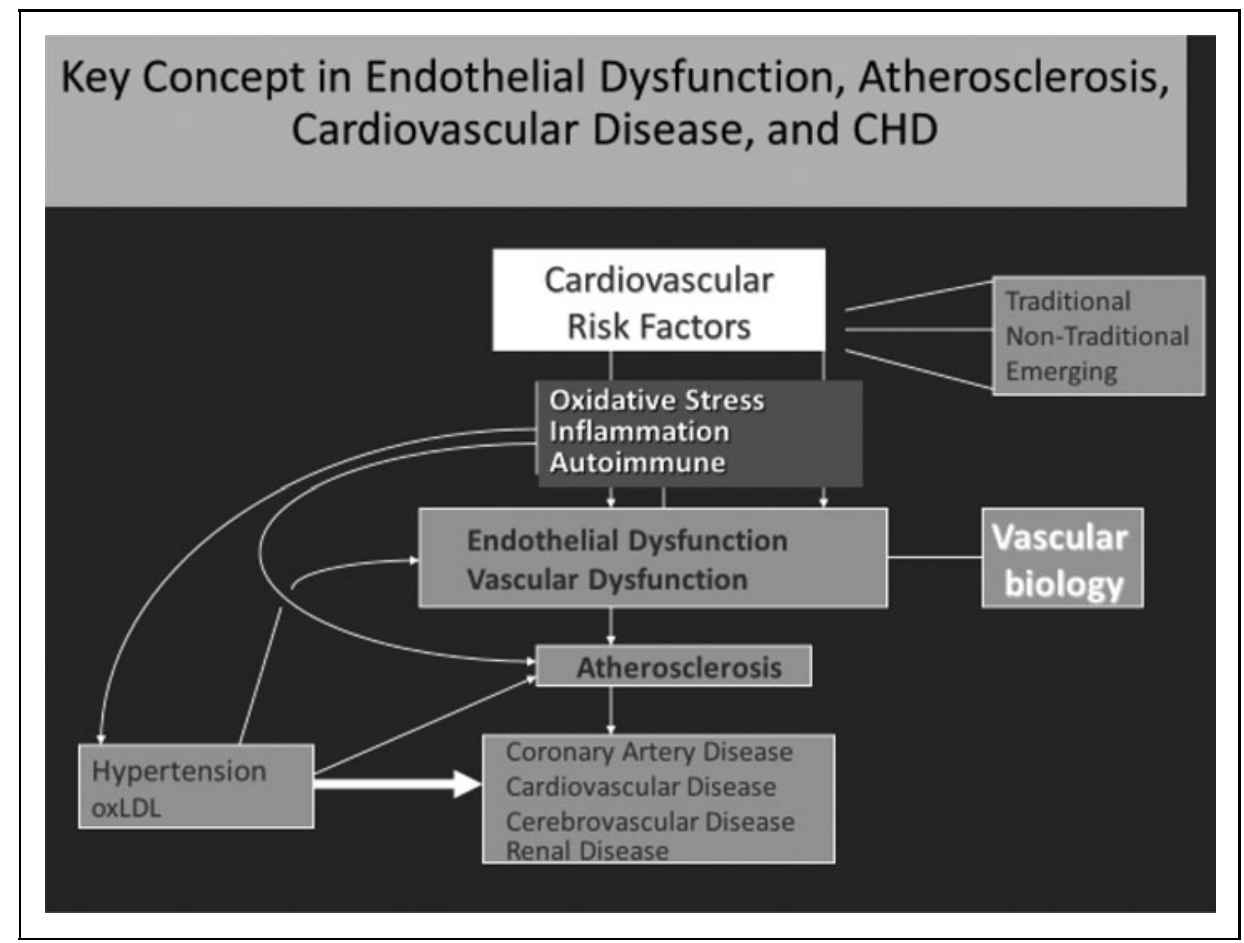

Figure 5. The three finite responses and vascular biology play a key role between CHD risk factors, endothelial and cardiovascular dysfunction, and CVD. ${ }^{206}$ 


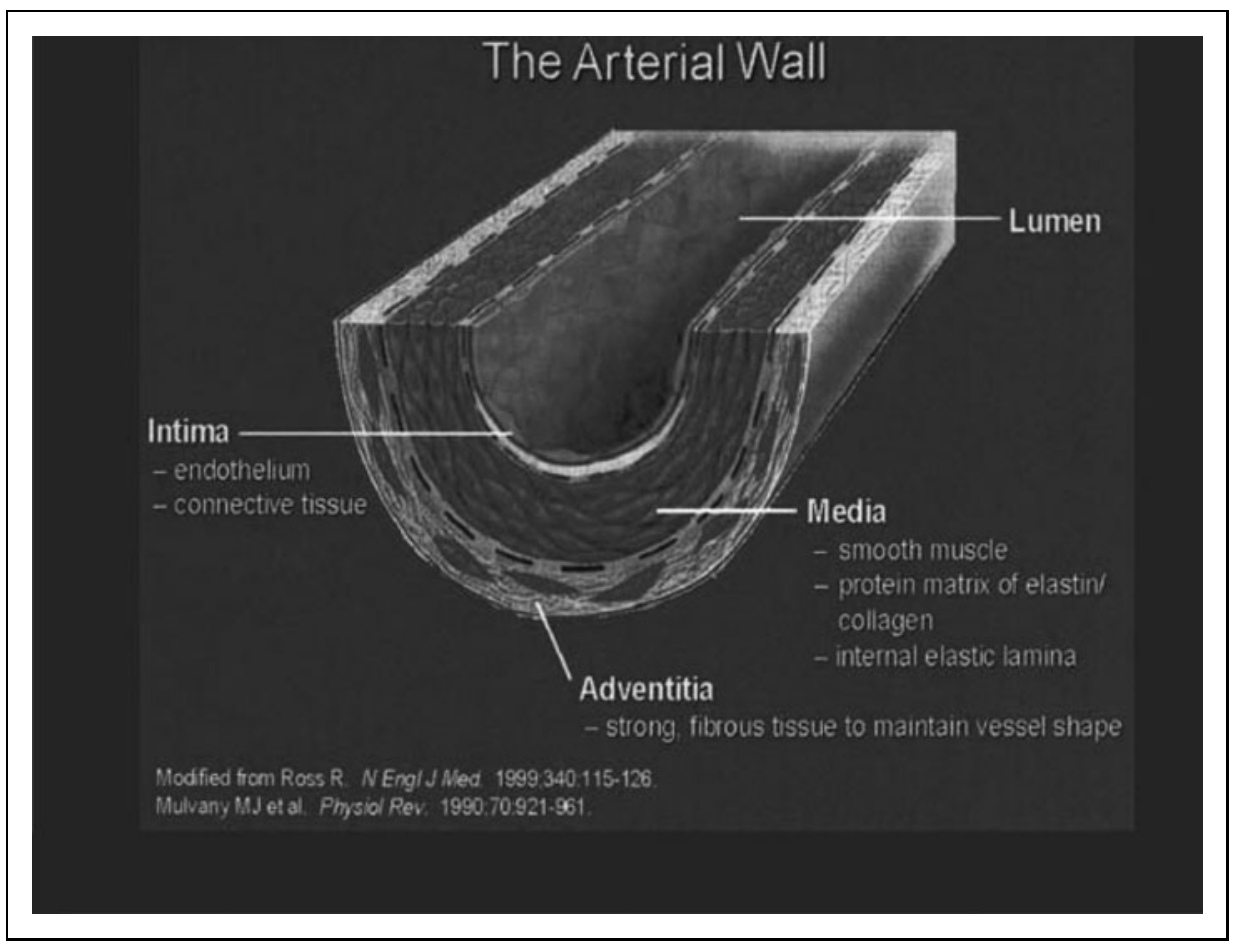

Figure 6. The blood vessel structure: endothelium, smooth muscle, and adventitia. The endothelium communicates with the luminal blood elements and the vascular media. ${ }^{205,206}$

channel blockers (CCB), angiotensin converting enzyme inhibitors (ACEI), and angiotensin receptor blockers (see Table $2) .{ }^{2-14}$ Numerous clinical nutrition studies have demonstrated the efficacy of dietary interventions for the prevention and treatment of hypertension, including Dietary Approaches to
Stop Hypertension (DASH 1 and DASH 2), the Mediterranean diet (MedDiet), Trials of Hypertension Prevention (TOHP 1 and TOHP 2), Trial of Nonpharmacologic Intervention in the Elderly (TONE), Treatment of Mild Hypertension (TOMHS), INTERMAP, INTERSALT, Premier, Vanguard, and others. ${ }^{2-5,10-14,51,52}$

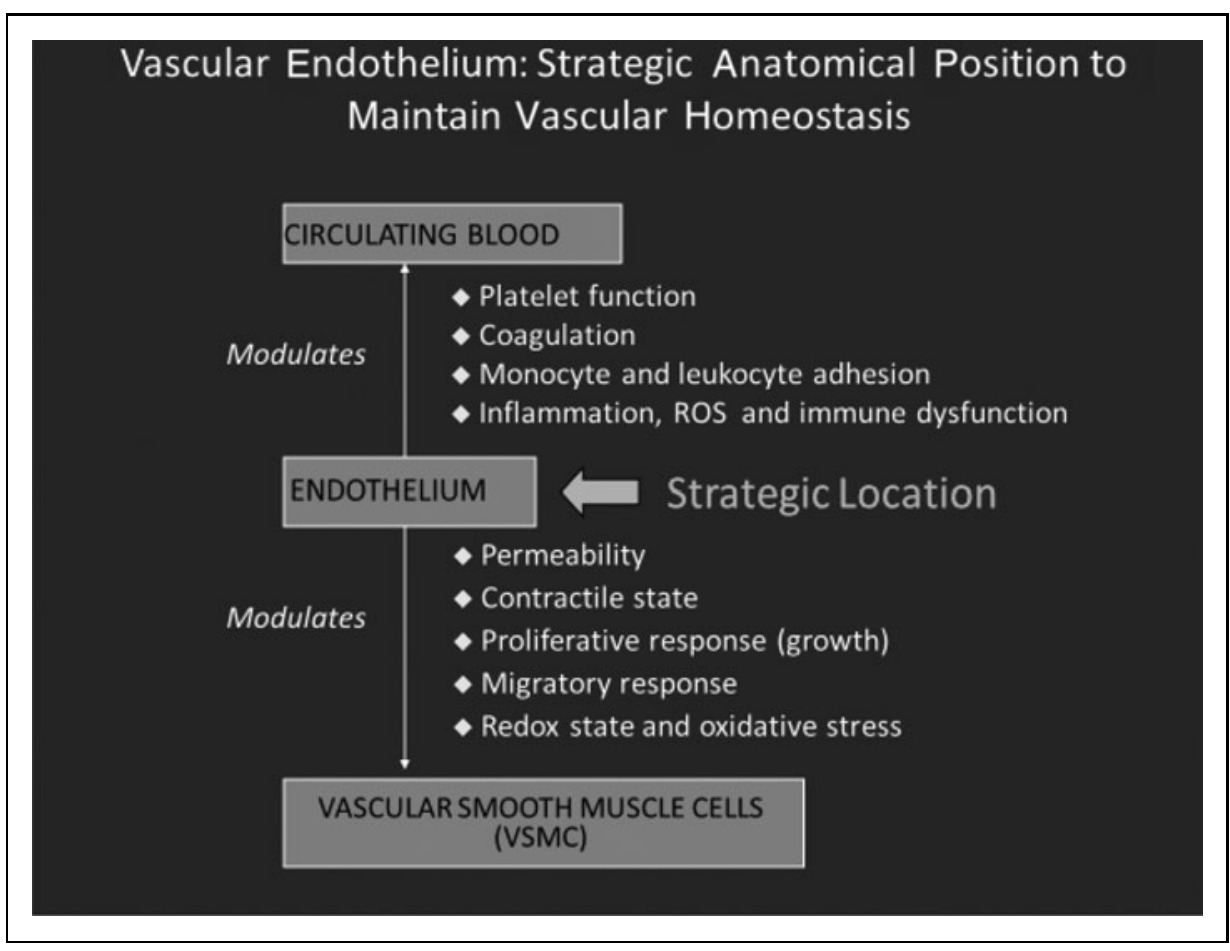

Figure 7. Vascular endothelium: strategic anatomical position to maintain vascular homeostasis. The endothelium has a stategic location and function to maintain communication and homeostasis between the circulating blood elements and the vascular smooth muscle. ${ }^{205,206}$ 


\section{Table 2. Natural Antihypertensive Compounds Categorized by Antihypertensive Class}

\section{Antihypertensive therapeutic} class (alphabetical listing)

Angiotensin converting

enzyme inhibitors
Calcium channel blockers

\section{Beta blockers}

Foods and ingredients listed by therapeutic class

Egg yolk

Fish (specific):

\begin{tabular}{l} 
Bonito \\
Dried salted fish \\
\hline Fish sauce
\end{tabular}

Fish sauce

Sardine muscle/protein

Tuna

Garlic

Gelatin

Hawthorne berry

Isoflavones/flavonoids

Milk products (specific):

Casein

Sour milk

Whey (hydrolyzed)

Protein

Sake

Sea vegetables (kelp)

Seaweed (wakame)

Sesame (also ET1)

Wheat germ (hydrolyzed)

Zein (corn protein)

Angiotensin receptor blockers

Celery

Fiber

Garlic

MUFA

Resveratrol

Potassium

Taurine

Vitamin C

Vitamin B6 (pyridoxine)

Hawthorne berry

\begin{tabular}{ll}
\hline Celery & Alpha lipoic acid \\
\hline Garlic & Calcium \\
\hline Hawthorn berry & Magnesium (PGE, NO) \\
\hline MUFA & N-acetyl cysteine \\
\hline & Oleic acid \\
\hline Omega-3 fatty acids: \\
\hline Eicosapentaenoic acid \\
\hline Docosahexaenoic acid \\
\hline Taurine \\
\hline
\end{tabular}

Nutrients and other supplements isted by therapeutic class

latonin

Probiotics

Pycnogenol

Quercetin

Coenzyme Q10

Gamma linolenic acid

NAC

Oleic acid

(1)

\begin{tabular}{ll}
\hline & Taurine \\
\hline Vitamin C \\
\hline Vitamin B
\end{tabular}




\begin{tabular}{|c|c|c|}
\hline \multirow[t]{3}{*}{$\begin{array}{l}\text { Antihypertensive therapeutic } \\
\text { class (alphabetical listing) }\end{array}$} & $\begin{array}{l}\text { Foods and ingredients listed } \\
\text { by therapeutic class }\end{array}$ & $\begin{array}{l}\text { Nutrients and other supplements } \\
\text { listed by therapeutic class }\end{array}$ \\
\hline & & Vitamin C \\
\hline & & Vitamin E \\
\hline \multirow{9}{*}{$\begin{array}{l}\text { Central alpha agonists } \\
\text { (reduce sympathetic } \\
\text { nervous system activity) }\end{array}$} & Celery & Coenzyme Q10 \\
\hline & Fiber & Gamma linolenic acid \\
\hline & Garlic & Potassium \\
\hline & Protein & Probiotics \\
\hline & & Restriction of sodium \\
\hline & & Taurine \\
\hline & & Vitamin C \\
\hline & & Vitamin B6 \\
\hline & & Zinc \\
\hline \multicolumn{2}{|l|}{ Direct renin inhibitors } & Vitamin D \\
\hline \multirow[t]{14}{*}{ Direct vasodilators } & Beets (NO, ED) & Alpha linolenic acid \\
\hline & Celery & Arginine \\
\hline & Cocoa (NO, ED) & Calcium \\
\hline & Cooking oils with monounsaturated fats & Carnitines (eNOS, NO) \\
\hline & Fiber & Flavonoids \\
\hline & Garlic & Grape seed extract \\
\hline & Hesperidin and orange juice & Lycopene (NO, ED) \\
\hline & Lycopene food (NO, ED) & Magnesium \\
\hline & MUFA & Melatonin (NO, ED) \\
\hline & Soy & Omega-3 fatty acids (NO, ED) \\
\hline & Teas: green and black & Potassium (NO, ED) \\
\hline & & Taurine \\
\hline & & Vitamin C \\
\hline & & Vitamin $\mathrm{E}$ \\
\hline \multirow[t]{11}{*}{ Diuretics } & Celery & Calcium \\
\hline & Fiber & Coenzyme Q10 \\
\hline & Hawthorn berry & Fiber \\
\hline & Protein & Gamma linolenic acid \\
\hline & & L-carnitine \\
\hline & & Magnesium \\
\hline & & Potassium \\
\hline & & Taurine \\
\hline & & Vitamin B6 \\
\hline & & Vitamin C \\
\hline & & $\begin{array}{l}\text { Vitamin E: high gamma/delta } \\
\text { tocopherols and tocotrienols }\end{array}$ \\
\hline
\end{tabular}

\section{Sodium}

Increased dietary sodium intake is associated with hypertension, cerebrovascular accident (CVA), left ventricular hypertrophy (LVH), diastolic dysfunction (DD), CHD, MI, renal insufficiency, proteinuria, arterial stiffness, platelet dysfunction, and increased sympathetic nervous system (SNS) activation. A reduction in dietary sodium intake lowers $\mathrm{BP}$ and the risk of all of these diseases. ${ }^{2-5,10-14,15,18,19,53-61}$ Decreasing dietary sodium intake in hypertensive patients, especially 
salt-sensitive patients, lowers BP by $4-6 / 2-3 \mathrm{mmHg}$ proportional to the amount of sodium restriction ${ }^{54}$ and may prevent or delay hypertension in high-risk patients.

Salt sensitivity, defined as a $\geq 10 \%$ increase in mean arterial pressure (MAP) with salt loading, increases the BP response to dietary salt intake in $51 \%$ of hypertensive patients overall, but may be even higher in African American hypertensive patients. ${ }^{57,58}$ Cardiovascular events may be more common in saltsensitive patients compared to salt-resistant patients, independent of BP level. ${ }^{57,58}$ Decreasing sodium intake to $<1500-2300 \mathrm{mg} /$ day was associated with lower BP and a decrease in all-cause mortality, whereas increasing the intake to $>2300 \mathrm{mg} /$ day was associated with an increase in all-cause mortality and CVD. ${ }^{56}$

Sodium promotes hypertension by increasing endothelial cell stiffness; reducing the size and pliability of endothelial cells; decreasing eNOS and NO production; elevating asymmetric dimethyl arginine, oxidative stress, and transforming growth factor beta; and abolishing AT2 receptor-mediated vasodilation. ${ }^{59,60,6263}$ All of these effects are increased in the presence of aldosterone, which mimics these same pathophysiologic changes. ${ }^{59-61,64,65}$ Endothelial cells act as vascular salt sensors. ${ }^{59,60}$

A balance of sodium with potassium and magnesium improves BP control and lowers cardiovascular and cerebrovascular events. ${ }^{2,65-69}$ Increasing the sodium/potassium ratio increases BP and the risk of CVD, but increasing the potassium/sodium ratio lowers $\mathrm{BP}$ and CVD risk. ${ }^{66-69}$ A potassium/sodium ratio of 4:1 is recommended, with a daily dietary sodium intake of $1500 \mathrm{mg}$ and a dietary potassium intake of $6000 \mathrm{mg}$.,66-69

\section{Potassium}

Increased dietary potassium intake reduces $\mathrm{BP}$ and $\mathrm{CVD}{ }^{66-73}$ The minimal recommended intake of potassium is $4700 \mathrm{mg} /$ day $(120 \mathrm{mmol})$, with a potassium/sodium ratio of $4-5: 1 .^{66-73}$ Potassium supplementation at $60 \mathrm{mmol} /$ day of potassium chloride for 12 weeks significantly reduced systolic BP (SBP; $5.0 \mathrm{mmHg}$ in 150 Chinese subjects). ${ }^{70}$ Prospective studies in a meta-analysis found that an intake of $\geq 1.64 \mathrm{~g} /$ day of potassium resulted in a $21 \%$ lower risk of stroke $(P=0.0007)$ and a lower risk of CHD and total CVD. In another meta-analysis, potassium supplementation resulted in modest but significant reductions in both SBP $(4.25 \mathrm{mmHg})$ and diastolic BP (DBP; $2.53 \mathrm{mmHg}){ }^{72}$ Studies indicate a dose-related reduction in BP of 4.4/2.5-8/ $4.1 \mathrm{mmHg}$ with potassium supplementation, with doses between 60 and $120 \mathrm{mmol} /$ day $^{2-14,66-73}$ Increased dietary potassium reduces CHD, MI, CHF, LVH, diabetes mellitus (DM) and cardiac arrhythmias independent of BP reduction. ${ }^{70}$ The incidence of CVA is reduced proportional to $\mathrm{BP}$ reduction, but also is independent of the BP reduction. ${ }^{2-14,66-73}$ Chronic serum levels of potassium $<4.0$ meq/dL increase CVD mortality while raising the risk of ventricular tachycardia, ventricular fibrillation, and CHF. ${ }^{2-14,66-73}$ Red blood cell potassium is a better indication of total body stores than serum potassium. ${ }^{2-14}$ Increasing potassium lowers NADPH oxidase, which reduces oxidative stress and inflammation. ${ }^{2-14,66-73}$
For each $1000 \mathrm{mg}$ increase in daily dietary potassium, allcause mortality is reduced by $20 \%$, and for each $1000 \mathrm{mg}$ decrease of daily dietary sodium intake, all-cause mortality is decreased by $20 \%{ }^{66}$ The recommended daily dietary intake of potassium is $6 \mathrm{~g}$ in hypertensive patients with normal renal function, those not taking potassium retaining medications, or those with some other contraindication..$^{2-14,66-73}$ Potassium sources include dark green leafy vegetables and fruits, nutritional supplements such as "No Salt" (KCL) substitutes, pure potassium powders, or combined potassium/magnesium powders and prescription $\mathrm{KCL}^{2-4}$

\section{Magnesium}

There is an inverse relationship between dietary magnesium intake and BP. ${ }^{67,74-78}$ In clinical trials, an increased dietary magnesium of $500-1000 \mathrm{mg} /$ day lowers BP, but compared to dietary potassium intake, the effect on BP results is less pronounced. ${ }^{67,74-78}$ Significant reductions in $\mathrm{BP}$ of 5.6/2.8 $\mathrm{mmHg}$, as documented by 24-hour ambulatory BP monitoring (ABPM) and home and office $\mathrm{BP}$ readings, usually take about two months. ${ }^{74} \mathrm{~A}$ meta-analysis of trials found that magnesium supplementation of $>370 \mathrm{mg} /$ day reduced BP by $3-4 \pm 2 \mathrm{mmHg} / 2.5 \pm 1 \mathrm{mmHg} .{ }^{77}$ A more recent meta-analysis (34 trials and 2028 participants) showed that magnesium supplementation dosed at $368 \mathrm{mg} /$ day for three months reduced BP by $2.00 / 1.78 \mathrm{mmHg}{ }^{76}$ The combination of high potassium and magnesium combined with a low sodium intake potentiates the antihypertensive effects in both treated and untreated hypertensive subjects. ${ }^{67,74-78}$ Magnesium also competes with sodium and calcium on vascular smoothmuscle binding sites, simulates the effects of $\mathrm{CCB}$, and increases NO levels and endothelial function. ${ }^{2,74-78}$

Intracellular erythrocyte levels of magnesium are a more accurate assessment of total body stores compared to serum levels. ${ }^{2,67,78}$ Magnesium formulations chelated to an amino acid, especially magnesium with taurine, provides additional BP reduction. ${ }^{2,67,78}$ Transdermal preparations of magnesium and magnesium salt baths are also effective. ${ }^{2,67,78} \mathrm{~A}$ high magnesium diet or magnesium supplements must be used with caution in patients taking medications that promote magnesium retention, in those with known renal insufficiency, or those with other contraindications to high doses of magnesium intake. The daily dose of magnesium seems to be the primary determinant of BP reduction regardless of the method of administration. Prospective studies comparing these different delivery systems have not been done., ${ }^{2,67,78}$

\section{Calcium}

Calcium supplementation is not recommended as an effective means to reduce BP until more studies are done on specific populations and age groups and the proper formulation and dose is identified. Calcium-containing foods are certainly safe to consume, but long-term use of calcium to improve BP has 
not been well documented. ${ }^{79-82}$ The only exception is that calcium may reduce the risk of pre-eclampsia and its comorbidities for both mother and fetus. ${ }^{82}$

\section{Zinc}

Low serum zinc levels correlate with hypertension and other cardiovascular problems. ${ }^{2,83,84}$ There is an inverse correlation between BP, serum zinc, and the zinc-dependent enzyme lysyl oxidase activity in hypertensive subjects. ${ }^{2,84}$ Zinc is transported into cardiac and vascular muscle and other tissues by metallothionein. ${ }^{83}$ Genetic deficiencies of metallothionein lead to intramuscular zinc deficiencies and hypertension. ${ }^{83}$ Zinc reduces oxidative stress, inflammation, and immune dysfunction and balances the reninangiotensin-aldosterone system (RAAS) and SNS. 1,2,57,58,83,84 Dietary zinc intake should be approximately $50 \mathrm{mg} / \mathrm{day}$, and levels should be monitored with serum zinc levels. ${ }^{1}$

\section{Protein}

Lower BP is associated with an increased intake of animal protein of all types and plant-based protein., ${ }^{2,68-115}$ Lean or wild-animal protein with a higher content of essential omega-3 FA and reduced saturated fat improves hypertension. ${ }^{86-89,115}$ Dietary protein intake $30 \%$ above the mean resulted in a $3.0 /$ $2.5 \mathrm{mmHg}$ lower BP compared to a dietary protein intake $30 \%$ below the mean $(81 \mathrm{~g} /$ day vs. $44 \mathrm{~g} /$ day $) .{ }^{2,85} \mathrm{In}$ a meta-analysis of 40 randomized controlled trials (RCTs), compared to carbohydrate, a higher dietary animal protein of any type and vegetable protein intake was associated with a reduction in mean BP of $1.2 / 0.6 \mathrm{mmHg}$. ${ }^{6,88}$

In a randomized crossover study of 352 pre-hypertension and stage I hypertension subjects, soy protein from food (not powder) and milk protein, both at $25 \mathrm{~g} /$ day, significantly reduced SBP by 2.0 and $2.3 \mathrm{mmHg}$, respectively, with no change in DBP compared to a high glycemic index diet. ${ }^{89}$ Soy protein intake of $25 \mathrm{~g} /$ day over three years was associated with a lower BP of 1.9/0.9 mmHg in 45,694 Chinese women. ${ }^{101}$ RCTs and meta-analyses of soy protein in hypertensive subjects indicate an average reduction in BP of $5.9 / 3.3 \mathrm{mmHg} .{ }^{101-103,105,106,108}$ The recommended daily intake of soy proteins from food is $25 \mathrm{~g}$.

Whey protein, milk peptides, fermented milk, and casein significantly lower BP in humans. ${ }^{2,6,90-95,104,110-115}$ Administration of $20 \mathrm{~g} /$ day of hydrolyzed whey protein lowered BP within six weeks by $8.0 / 5.5 \mathrm{mmHg} .{ }^{91}$ Milk peptides are rich in ACEI peptides, which lower BP by approximately 4.8/ $2.2 \mathrm{mmHg}$ with doses of 5-60 mg/day. ${ }^{2,6,90-95,104}$ Powdered fermented milk containing Lactobacillus helveticus and active ACEI peptides, dosed at $12 \mathrm{~g}$ /day, significantly reduced BP by $11.2 / 6.5 \mathrm{mmHg}$ in one month. ${ }^{92}$ Administration of $20 \mathrm{~g}$ of hydrolyzed whey protein to hypertensive subjects lowered BP by $11 / 7 \mathrm{mmHg}$ compared to controls within one week. ${ }^{95}$ The WHEY2Go trial ${ }^{110}$ was a randomized, double-blind, three-way crossover, controlled intervention study of 42 participants who were randomly assigned to consume $56 \mathrm{~g}$ of whey protein, $56 \mathrm{~g}$ of calcium caseinate, or $54 \mathrm{~g}$ of maltodextrin (control)/day for eight weeks separated by a fourweek washout. The 24-hour ABPM reductions in BP were $3.9 / 2.5 \mathrm{mmHg}(P=0.05)$, and peripheral and central SBP fell by $5.7 \mathrm{mmHg}(P=0.007)$ and $5.4 \mathrm{mmHg}(P=0.012)$, respectively, after whey protein consumption compared to the control groups, which did not significantly decrease BP. ${ }^{110}$ Whey protein improves endothelial function, stimulates opioid receptors, and improves PWV.

Marine collagen peptides (MCPs) derived from deep-sea fish have antihypertensive activity. ${ }^{96-98}$ Bonito protein (Sarda orientalis) from the tuna and mackerel family contains natural ACEI inhibitory peptides, and a dose of $1.5 \mathrm{~g} /$ day lowers BP by $10.2 / 7 \mathrm{mmHg}{ }^{97}$ Administration of MCPs in a double-blind placebo-controlled trial of 100 hypertensive diabetic subjects for three months significantly reduced DBP and MAP. ${ }^{96}$

Sardine muscle protein $(3 \mathrm{mg}$ of VAL-TYR, a sardine muscle concentrated extract) lowered BP by $9.7 / 5.3 \mathrm{mmHg}$ $(P<0.05)$ over four weeks in 29 hypertensive subjects. ${ }^{99} \mathrm{~A}$ vegetable drink with sardine protein hydrolysates also reduced BP by $8 / 5 \mathrm{mmHg}$ over 13 weeks. ${ }^{100}$

The daily recommended intake of protein from all sources is $1.0-1.5 \mathrm{~g} / \mathrm{kg}$ body weight, depending on exercise level, sex, age, hepatic and renal function, medications such as proton pump inhibitors and $\mathrm{H} 2$ blockers, and concomitant medical diseases. $^{2}$

\section{L-arginine}

$\mathrm{L}$ arginine lowers BP in humans, with a low side-effect profile and levels similar to the DASH diet. ${ }^{116-128} \mathrm{~L}$-arginine and endogenous methylarginines are the primary precursors used by eNOS to produce NO. ${ }^{116-122}$

Intracellular arginine levels far exceed the $\mathrm{K}_{\mathrm{m}}$ of eNOS under normal physiological conditions, but endogenous NO formation depends on extracellular arginine concentration. NO production by endothelial cells is closely coupled to cellular arginine transport mechanisms that regulate NO-dependent functions such as increasing renal vascular flow, renal perfusion, renal tubular NO bioavailability, and BP. ${ }^{121}$

Parenteral and oral L-arginine administration in hypertensive and normotensive subjects lowers BP significantly at doses of 10 $12 \mathrm{~g} /$ day in food or as a supplement. Arginine administration lowers BP by about $6.2 / 6.8 \mathrm{mmHg}$ in both office and 24-hour ABPM readings. ${ }^{16,117,123,125,126}$ Arginine administered at 4 g/day significantly lowered BP in gestational hypertension, reduced concomitant antihypertensive therapy, and improved maternal and neonatal outcomes with normal delivery time. ${ }^{123,124}$ The combination of arginine $(1200 \mathrm{mg} /$ day $)$ and N-acetyl cysteine $(600 \mathrm{mg}$ b.i.d.) administered over six months to hypertensive patients with type $2 \mathrm{DM}$ lowered SBP and DBP $(P<0.05) .{ }^{125}$ Arginine may have a pro-oxidative effect and increase mortality in patients with advanced atherosclerosis, CHD, acute coronary 
syndrome, or MI. ${ }^{127}$ Pending more studies, arginine is best avoided in these situations. There are no data on L-citrulline in these settings.

\section{Taurine}

Taurine is a conditionally essential sulfur-based amino acid that is efficacious for the treatment of hypertension and a variety of CVDs by reducing SNS activity, plasma norepinephrine, and plasma and urinary epinephrine..$^{2-5,14,129-136}$ In addition, taurine increases urinary sodium and water excretion, atrial natriuretic factor (ANF), and NO bioavailability; improves ED; and increases EPCs, while it decreases plasma renin activity, A-II, and plasma aldosterone. ${ }^{2-5,129-131}$ Nineteen hypertensive subjects administered $6 \mathrm{~g}$ of taurine daily lowered BP by $9 / 4.1 \mathrm{mmHg}(P<0.05)$ in seven days. ${ }^{130} \mathrm{In}$ a randomized, double-blind, placebo-controlled study over 12 weeks in 120 prehypertensive individuals, taurine supplementation ( $1.6 \mathrm{~g} /$ day) significantly improved endothelial function and decreased the clinic and 24-hour ABPM reading by $7.2 / 2.6 \mathrm{mmHg}$ and $4.7 / 1.3 \mathrm{mmHg}$, respectively. ${ }^{136} \mathrm{In}$ another four-month study of 97 pre-hypertensive individuals, $1.6 \mathrm{~g}$ /day of taurine significantly decreased the clinic and 24hour ABPM, improved endothelium vasodilation, and reduced the carotid IMT. ${ }^{134}$

In a randomized, double-blind, placebo-controlled study of 42 hypertensive subjects evaluated over one month, a combination powder dietary supplement was given once daily. ${ }^{135}$ The supplement included $6 \mathrm{~g}$ of taurine, $1000 \mathrm{mg}$ of vitamin C (as magnesium ascorbate), $150 \mathrm{mg}$ of grape seed extract, $87 \mathrm{mg}$ of magnesium ascorbatet, $100 \mathrm{mg}$ of vitamin B6 (pyridoxine $\mathrm{HCl}$ ), $2000 \mathrm{IU}$ of vitamin $\mathrm{D} 3$, and $2 \mathrm{mg}$ of biotin. The active group had a reduction in $\mathrm{BP}$ of $16 / 11.35 \mathrm{mmHg}(P<0.001)$ at week 4 . The recommended dose of taurine is $1.5-6 \mathrm{~g} /$ day as a single dose or in divided doses. ${ }^{2,129-136}$

\section{Omega-3 Fats and Selected Omega-6 Fats}

Omega-3 FA derived from food or nutritional supplements produce a dose-related reduction in BP and CVD in published human studies..$^{2-14,115,137-152}$ A meta-analysis of 70 RCTs found that compared to placebo, the consumption of omega-3 polyunsaturated FA (PUFAs; 0.3-15 g/day) for 4-26 weeks significantly reduced BP by $1.5 / 1.0 \mathrm{mmHg} .{ }^{146}$ The largest BP reductions were in untreated hypertensive subjects $(\mathrm{SBP}=$ $4.5 \mathrm{mmHg}$ [ $95 \%$ confidence interval $(\mathrm{CI})-6.1$ to $-2.8 \mathrm{mmHg}$; $\mathrm{DBP}=-3.0 \mathrm{mmHg}[95 \% \mathrm{CI}-4.3$ to $-1.7 \mathrm{mmHg}]) .{ }^{146} \mathrm{~A}$ second meta-analysis of RCTs found that omega-3 FA supplementation for 6-105 weeks at 900-3000 mg/day improved PWV $(P<0.01)$ and arterial compliance $(P<0.001) .{ }^{147}$ Docosahexaenoic acid (DHA) is more effective than eicosapentaenoic acid (EPA) in reducing BP by an average of 8/ $5 \mathrm{mmHg}$ and also lowering the resting heart rate by $6 \mathrm{bpm}$ and improving heart rate variability. ${ }^{2-14,137-139,142-144}$
Administration of EPA and DHA is preferred to alpha linolenic acid due to the latter's minimal conversion to these longer-chain omega-3 FA. ${ }^{2-14,138,140}$ The consumption of cold-water fish three times per week reduces BP due to the combination of protein and omega- $3 \mathrm{FA}^{2-14,109,138}$ In patients with chronic kidney disease, $4 \mathrm{~g}$ of omega-3 FA significantly lowered 24-hour BP (ABPM) by $3.3 / 2.9 \mathrm{mmHg}$ compared to placebo $(P<0.0001) .{ }^{139}$ Omega-6 FA, gammalinolenic acid (GLA), and dihomo-gamma linolenic acid reduce BP and prevent elevations in BP induced by saturated fats. ${ }^{143}$ GLA blocks stress-induced hypertension, lowers aldosterone levels, decreases adrenal AT1R density and affinity, and increases the vasodilating prostaglandins E1 (PGE1) and PGI2. ${ }^{2-14,143}$

Omega-3 FA reduce CHD and $\mathrm{MI}^{152}$; increase eNOS and NO; improve endothelial function; reduce arterial stiffness; decrease PWV, insulin resistance, and plasma norepinephrine; suppress ACE activity; and increase parasympathetic tone at doses of $900-3000 \mathrm{mg} /$ day $^{2-14,137,145,148}$ The recommended daily dose is $3000-5000 \mathrm{mg} /$ day of combined DHA and EPA at a ratio of three parts EPA to two parts DHA, with 50\% of this dose as GLA combined with gamma plus delta tocopherols at $100 \mathrm{mg} / \mathrm{g}$ of DHA and EPA to get the red blood cell membrane omega-3 index at $8 \%{ }^{2-5}$ There are no adverse effects or safety concerns at these recommended doses. ${ }^{2-14}$

\section{Monounsatured FA: Olive Oil, MedDiet, Omega-9 Fats, Oleic Acid, and Olive Leaf Extract}

The MedDiet, which is rich in olive oil and olive leaf extracts (OLE), reduces BP and CVD in most clinical trials. ${ }^{2-14,153-176}$ In an open study over two months, 40 borderline hypertensive monozygotic twins given either 500 or $1000 \mathrm{mg}$ /day of OLE had significant reductions in $\mathrm{BP}$ of $6 / 5 \mathrm{mmHg}$ (500 $\mathrm{mg}$ of OLE) and 13/5 mmHg (1000 of OLE) compared to controls. ${ }^{176}$ In another randomized, double-blind placebo-controlled trial, the BP decreased by $8 / 6 \mathrm{mmHg}(P \leq 0.01)$ in office and 24-hour $\mathrm{ABPM}$, and the need for antihypertensive medications reduced by $48 \%$ in the monounsaturated fatty acid (MUFA) group $(P<0.005) .{ }^{153}$ Extra virgin olive oil (EVOO) lowered the SBP by $14 \mathrm{mmHg}$ in elderly hypertensive patients $(P<0.01) .{ }^{154,155}$ EVOO contains lipid-soluble phytonutrients such as nitrates and polyphenols, which lower BP by reducing oxidative stress and oxLDL, blocking the AT1R, altering RAAS and endothelin gene expression, increasing NO levels and endothelial induced vasodilation, and blocking calcium channels similar to a CCB. ${ }^{150,153,157,164-166}$ EVOO with a total phenol content of at least $161 \mathrm{mg} / \mathrm{kg}$ at $20-40 \mathrm{~g}$ (2-4 tbsp) per day will significantly lower SBP in about three weeks. EVOO with $300 \mathrm{mg} / \mathrm{kg}$ of total phenols may also decrease DBP. ${ }^{2-5,170}$

A total of 166 elderly subjects were prescribed a MedDiet or their habitual diet (HabDiet; control) for six months. ${ }^{174}$ Compared to the HabDiet, the MedDiet lowered SBP by 
$1.1 \mathrm{mmHg}$ and improved flow-mediated vasodilation at six months $(P=0.01)$. The INTERMAP trial found that dietary MUFA intake, especially oleic acid from vegetable sources, may contribute to the prevention and control of adverse BP levels in the general population. ${ }^{175}$

In the European Prospective Investigation into Cancer and Nutrition (EPIC) study (20,343 subjects), the intake of EVOO and polyphenols documented an inverse relationship with SBP and DBP. ${ }^{171}$ In the Prevention with Mediterranean Diet (PREDIMED) trial that included 7447 patients at high risk for CVD, the participants on the MedDiet supplemented with EVOO had a significantly lower DBP than those in the control group $(1.5 \mathrm{mmHg}) .{ }^{172}$

OLE is associated with a dose-dependent reduction in BP, with a range of $4 / 3-11 / 5 \mathrm{mmHg}$ with both office BP measurements and 24-hour ABPM. ${ }^{167-169,173} \mathrm{~A}$ total of 60 pre-hypertensive male subjects in a six-week study with OLE demonstrated a reduction in BP of about $4 / 3 \mathrm{mmHg} .{ }^{167}$ Olive (Olea europaea) leaf extract, at the dosage regimen of $500 \mathrm{mg}$ b.i.d., was similarly effective in lowering SBP and DBP in subjects with stage 1 hypertension compared to captopril, given at its effective dose of $12.5-25 \mathrm{mg}$ b.i.d. (reduction of about $11 / 5 \mathrm{mmHg}$ ). ${ }^{169}$

\section{Vitamin C}

Dietary intake of vitamin $\mathrm{C}$ and plasma ascorbate concentration in humans are inversely correlated to BP. ${ }^{2-14,177-199}$ The administration of vitamin $\mathrm{C}$ orally and intravenously reduced BP in clinical trials. ${ }^{2-14,177-199}$ Thirty-one patients were randomized to 500,1000 , or $2000 \mathrm{mg}$ of oral vitamin $\mathrm{C}$ daily, with a mean reduction in BP of $4.5 / 2.8 \mathrm{mmHg}(P<0.05) .{ }^{194}$ There was no difference between the three vitamin $C$ groups, indicating that $500 \mathrm{mg}$ daily or $250 \mathrm{mg}$ b.i.d. is sufficient to reduce BP. ${ }^{194}$ In a meta-analysis of 29 trials with a median dose of vitamin $\mathrm{C}$ of $500 \mathrm{mg} /$ day and a median duration of two months, there was a significant reduction in BP of 3.84/ $1.48 \mathrm{mmHg}(P=0.04) .{ }^{199}$ Published clinical trials show that vitamin $\mathrm{C}$ at a dose of $250 \mathrm{mg}$ b.i.d. reduces $\mathrm{BP}$ by an average of 7/4 mmHg. ${ }^{2-14,177-199}$ Vitamin $\mathrm{C}$ is a potent water-soluble antioxidant and electron donor that recycles vitamin $\mathrm{E}$ and other antioxidants and enhances total antioxidant capacity. ${ }^{177}$ In elderly patients with refractory hypertension already on maximum pharmacologic therapy, $600 \mathrm{mg}$ of vitamin $\mathrm{C}$ daily lowered BP by an additional 20/16 mmHg. ${ }^{186}$ Plasma ascorbate is inversely correlated with BP in healthy, normotensive individuals, and those with the lowest initial ascorbate serum levels have the best BP reduction. ${ }^{2-5,187,193}$ SBP and the 24hour ABPM show the most significant reductions with chronic oral administration of vitamin C. ${ }^{2,181-186}$ In a depletionrepletion study of vitamin $\mathrm{C}$, Block et al. ${ }^{187}$ demonstrated an inverse correlation of plasma ascorbate levels, SBP, and DBP. In a meta-analysis of 13 clinical trials with 284 patients, vitamin $\mathrm{C}$ at $500 \mathrm{mg} /$ day over six weeks reduced BP by 3.9/ $2.1 \mathrm{mmHg} .{ }^{188}$ Hypertensive subjects have significantly lower plasma ascorbate levels compared to normotensive subjects
(40 $\mu \mathrm{mol} / \mathrm{L}$ vs. $57 \mu \mathrm{mol} / \mathrm{L}$, respectively). ${ }^{190,199}$ A serum level of $100 \mu \mathrm{mol} / \mathrm{L}$ is recommended for optimal BP lowering. ${ }^{2-5}$

\section{Vitamin E}

Very few clinical studies have demonstrated improved BP with supplementation with the various types of tocopherols or tocotrienols. ${ }^{2,200-204}$ Patients with type 2 DM on prescription medications with controlled BP (average BP of $136 / 76 \mathrm{mmHg}$ ) were administered $400 \mathrm{mg}$ of mixed tocopherols containing $60 \%$ gamma, $25 \%$ delta, and $15 \%$ alpha tocopherols. ${ }^{200}$ The BP increased by $6.8 / 3.6 \mathrm{mmHg}$ in the study patients on the mixed tocopherols $(P<0.0001)$ and increased even more in those subjects taking alpha tocopherol (BP increased by $7 /$ $5.3 \mathrm{mmHg} ; P<0.0001){ }^{200}$ The BP increase was likely due to drug interactions with tocopherols via cytochrome P450-3A4 and $4 \mathrm{~F} 2$ that decreased the effective serum levels of the antihypertensive medications. ${ }^{200}$ Gamma tocopherol has an antihypertensive and natriuretic effect through the inhibition of the $70 \mathrm{pS}$ potassium channel in the thick ascending limb of the loop of Henle. ${ }^{201}$ Both alpha and gamma tocopherol improve insulin sensitivity and enhance adiponectin expression via a PPAR- $\gamma$-dependent process, which has the potential to lower $\mathrm{BP}$ and serum glucose. ${ }^{202}$

In a retrospective analysis and data from the National Health and Nutrition Survey, the medium and high tertiles of vitamin E intake were associated with a significantly lower odds ratio for hypertension $\left(0.73\right.$ and 0.81 , respectively). ${ }^{203}$ In a randomized, double-blind, placebo-controlled trial of 58 individuals with type $2 \mathrm{DM}, 500 \mathrm{mg} /$ day of RRR- $\alpha$-tocopherol, $500 \mathrm{mg} /$ day of mixed tocopherols, or placebo for six weeks did not significantly alter the rate of daytime or night-time SBP, DBP, or pulse pressure variation compared to placebo $(P>0.05){ }^{204}$ If vitamin $\mathrm{E}$ has an antihypertensive effect, it is probably small and may be limited to patients with untreated hypertension, vitamin $\mathrm{E}$ deficiency, known vascular disease, mild volume overload, or other concomitant problems such as DM or hyperlipidemia. ${ }^{2-5,200-204}$

\section{References}

1. Wesa KM, Grimm RH. Recommendations and guidelines regarding the preferred research protocol for investigating the impact of an optimal healing environment on patients with hypertension. J Altern Complement Med 2004; 10:S245-S250

2. Houston M. The role of nutrition and nutraceutical supplements in the treatment of hypertension. World J Cardiol 2014;6:38-66.

3. Houston M. Nutrition and nutraceutical supplements for the treatment of hypertension: Part 1. J Clinical Hypertension 2013;15:752-757.

4. Houston M. Nutrition and nutraceutical supplements for the treatment of hypertension: Part II. J Clinical Hypertension 2013;15:845-851.

5. Houston M. Nutrition and nutraceutical supplements for the treatment of hypertension: Part III. J Clinical Hypertension 2013;15:931-937.

6. Borghi C, Cicero AF. Nutraceuticals with a clinically detectable blood pressure-lowering effect: A review of available randomized clinical trials and their meta-analyses. Br J Clin Pharmacol 2017;83:163-171. 
7. Sirtori CR, Arnoldi A, Cicero AF. Nutraceuticals for blood pressure control. Ann Med 2015;47:447-456.

8. Cicero AF, Colletti A. Nutraceuticals and blood pressure control: Results from clinical trials and meta-analyses. High Blood Press Cardiovasc Prev 2015;22:203-213.

9. Turner JM, Spatz ES. Nutritional supplements for the treatment of hypertension: A practical guide for clinicians. Curr Cardiol Rep 2016;18:126.

10. Caligiuri SP, Pierce GN. A review of the relative efficacy of dietary, nutritional supplements, lifestyle and drug therapies in the management of hypertension. Crit Rev Food Sci Nutr 2017;57:3508-3527.

11. Houston MC, Fox B, Taylor N. What Your Doctor May Not Tell You About Hypertension. The Revolutionary Nutrition and Lifestyle Program to Help Fight High Blood Pressure. New York: AOL Time Warner, Warner Books, 2003.

12. Houston MC. Handbook of Hypertension. Oxford: Wiley-Blackwell, 2009.

13. Houston MC. What Your Doctor May Not Tell You About Heart Disease. New York: Grand Central Press, 2012.

14. Sinatra $S$, Houston $M$, eds. Nutrition and Integrative Strategies in Cardiovascular Medicine. Boca Raton, FL: CRC Press, 2015.

15. Chobanian AV, Bakris GL, Black HR, et al. The Seventh Report of the Joint National Committee on Prevention, Detection, Evaluation, and Treatment of High Blood Pressure: The JNC 7 report. JAMA 2003;289:2560-2572.

16. Thomopoulos C, Parati G, Zanchetti A. Effects of blood pressure lowering on outcome incidence in hypertension: 7. Effects of more vs. less intensive blood pressure lowering and different achieved blood pressure levelsUpdated overview and meta-analyses of randomized trials. J Hypertens 2016; 34:613-622.

17. Ettehad D, Emdin CA, Kiran A, et al. Blood pressure lowering for prevention of cardiovascular disease and death: A systematic review and metaanalysis. Lancet 2016;387:957-967.

18. ESH/ESC Task Force for the Management of Arterial Hypertension. 2013 Practice guidelines for the management of arterial hypertension of the European Society of Hypertension (ESH) and the European Society of Cardiology (ESC): ESH/ESC Task Force for the Management of Arterial Hypertension. J Hypertens 2013;31:1925-1938.

19. Flack JM, Calhoun D, Schiffrin EL. The New ACC/AHA hypertension guidelines for the prevention, detection, evaluation, and management of high blood pressure in adults. Am J Hypertens 2018;31:133-135.

20. Appel LJ. American Society of Hypertension Writing Group. ASH position paper: Dietary approaches to lower blood pressure. J Am Soc Hypertens 2009;3:321-331.

21. Eaton SB, Eaton SB III, Konner MJ. Paleolithic nutrition revisited: A twelve-year retrospective on its nature and implications. Eur J Clin Nutr 1997;51:207-216.

22. Layne J, Majkova Z, Smart EJ, et al. Caveolae: A regulatory platform for nutritional modulation of inflammatory diseases. J Nutr Biochem 2011;22: $807-811$.

23. Dandona $\mathrm{P}$, Ghanim H, Chaudhuri A, et al. Macronutrient intake induces oxidative and inflammatory stress: Potential relevance to atherosclerosis and insulin resistance. Exp Mol Med 2010;42:245-253.

24. Kizhakekuttu TJ, Widlansky ME. Natural antioxidants and hypertension: Promise and challenges. Cardiovasc Ther 2010;28:e20-e32.

25. Houston MC. New insights and approaches to reduce end organ damage in the treatment of hypertension: Subsets of hypertension approach. Am Heart J 1992;123:1337-1367.

26. Nayak DU, Karmen C, Frishman WH, Vakili BA. Antioxidant vitamins and enzymatic and synthetic oxygen-derived free radical scavengers in the prevention and treatment of cardiovascular disease. Heart Dis 2001;3:28-45.

27. Ritchie RH, Drummond GR, Sobey CG, et al. The opposing roles of NO and oxidative stress in cardiovascular disease. Pharmacol Res 2017;116:57-69.
28. Russo C, Olivieri O, Girelli D, et al. Antioxidant status and lipid peroxidation in patients with essential hypertension. J Hypertens 1998;16:12671271.

29. Tse WY, Maxwell SR, Thomason H, et al. Antioxidant status in controlled and uncontrolled hypertension and its relationship to endothelial damage. J Hum Hypertens 1994;8:843-849.

30. Galley HF, Thornton J, Howdle PD, et al. Combination oral antioxidant supplementation reduces blood pressure. Clin Sci 1997;92:361-365.

31. Dhalla NS, Temsah RM, Netticadam T. The role of oxidative stress in cardiovascular diseases. J Hypertens 2000;18:655-673.

32. Loperena R, Harrison DG. Oxidative stress and hypertensive diseases. Med Clin North Am 2017;101:169-193.

33. Pietri P, Vlachopoulos $\mathrm{C}$, Tousoulis D. Inflammation and arterial hypertension: From pathophysiological links to risk prediction. Curr Med Chem 2015;22:2754-2761.

34. Amer MS, Elawam AE, Khater MS, et al. Association of high-sensitivity $\mathrm{C}$ reactive protein with carotid artery intima-media thickness in hypertensive older adults. J Am Soc Hypertens 2011;5:395-400.

35. Kvakan H, Luft FC, Muller DN. Role of the immune system in hypertensive target organ damage. Trends Cardiovasc Med 2009;19:242-246.

36. Rodriguez-Iturbe B, Franco M, Tapia E, et al. Renal inflammation, autoimmunity and salt-sensitive hypertension. Clin Exp Pharmacol Physiol 2012; 39:96-103.

37. Mansego ML, Solar Gde M, Alonso MP, et al. Polymorphisms of antioxidant enzymes, blood pressure and risk of hypertension. J Hypertens 2011; 29:492-500.

38. Vongpatanasin W, Thomas GD, Schwartz R, et al. C-reactive protein causes downregulation of vascular angiotensin subtype 2 receptors and systolic hypertension in mice. Circulation 2007;115:1020-1028.

39. Razzouk, Munter $\mathrm{P}$, Bansilal $\mathrm{S}$, et al. C reactive protein predicts long-term mortality independently of low-density lipoprotein cholesterol in patients undergoing percutaneous coronary intervention. Am Heart J 2009;158:277283.

40. Tian N, Penman AD, Mawson AR, et al. Association between circulating specific leukocyte types and blood pressure. The Atherosclerosis Risk in Communities (ARIC) study. J Am Soc Hypertens 2010;4:272-283.

41. Muller DN, Kvakan H, Luft FC. Immune-related effects in hypertension and target-organ damage. Curr Opin Nephrol Hypertens 2011;20:113-117.

42. Leibowitz A, Schiffin EL. Immune mechanisms in hypertension. Curr Hypertens Rep 2011;13:465-472.

43. Xiong $\mathrm{S}$, Li Q, Liu D, Zhu Z. Gastrointestinal tract: A promising target for the management of hypertension. Curr Hypertens Rep 2017;19:31.

44. Caillon A, Mian MO, Fraulob-Aquino JC, et al. Gamma delta T cells mediate angiotensin II-induced hypertension and vascular injury. Circulation 2017;135:2155-2162.

45. Rudemiller NP, Crowley SD The role of chemokines in hypertension and consequent target organ damage. Pharmacol Res 2017;119:404-411.

46. De Ciuceis C, Agabiti-Rosei C, Rossini C, et al. Relationship between different subpopulations of circulating $\mathrm{CD} 4+\mathrm{T}$ lymphocytes and microvascular or systemic oxidative stress in humans. Blood Press 2017;26:237-245.

47. Caillon A, Schiffrin EL. Role of inflammation and immunity in hypertension: Recent epidemiological, laboratory, and clinical evidence. Curr Hypertens Rep 2016;18:21.

48. Abais-Battad JM, Dasinger JH, Fehrenbach DJ, Mattson DL. Novel adaptive and innate immunity targets in hypertension. Pharmacol Res 2017; 120:109-115.

49. Biancardi VC, Bomfim GF, Reis WL, et al. The interplay between angiotensin II, TLR4 and hypertension. Pharmacol Res 2017;120:88-96.

50. Justin Rucker A, Crowley SD. The role of macrophages in hypertension and its complications. Pflugers Arch 2017;469:419-430. 
51. Miller ER 3rd, Erlinger TP, Appel LJ. The effects of macronutrients on blood pressure and lipids: An overview of the DASH and OmniHeart trials. Curr Atheroscler Rep 2006;8:460-465.

52. Pérez-López FR, Chedraui $\mathrm{P}$, Quadro JL. Effects of the Mediterranean diet on longevity and age-related morbid conditions. Maturitas 2009;64:67-79.

53. Cutler JA, Follmann, Allender PS. Randomized trials of sodium reduction: An overview. Am J Clin Nutr 1997;65:643S-651S.

54. Sacks FM, Svetkey LP, Vollmer WM, et al. Effects on blood pressure of reduced dietary sodium and the Dietary Approaches to Stop Hypertension (DASH) diet. DASH-Sodium Collaborative Research Group. N Engl J Med 2001;4;344:3-10.

55. Messerli FH, Schmieder RE, Weir MR. Salt: A perpetrator of hypertensive target organ disease? Arch Intern Med 1997;157:2449-2452.

56. Merino J, Guasch-Ferré M, Martínez-González MA, et al. Is complying with the recommendations of sodium intake beneficial for health in individuals at high cardiovascular risk? Findings from the PREDIMED study. Am J Clin Nutr 2015;101:440-448.

57. Weinberger MH. Salt sensitivity of blood pressure in humans. Hypertension 1996;27:481-490.

58. Morimoto A, Usu T, Fujii T, et al. Sodium sensitivity and cardiovascular events in patients with essential hypertension. Lancet 1997;350:1734-1737.

59. Kanbay M, Chen Y, Solak Y, Sanders PW. Mechanisms and consequences of salt sensitivity and dietary salt intake. Curr Opin Nephrol Hypertens 2011;20:37-43.

60. Toda N, Arakawa K. Salt-induced hemodynamic regulation mediated by nitric oxide. J Hypertens 2011;29:415-424.

61. Rust $P$, Ekmekcioglu C. Impact of salt intake on the pathogenesis and treatment of hypertension. Adv Exp Med Biol 2017;956:61-84.

62. Toda N, Arakawa K. Salt-induced hemodynamic regulation mediated by nitric oxide. J Hypertens 2011;29:415-424.

63. Foulquier S, Dupuis F, Perrin-Sarrado C, et al. High salt intake abolishes AT(2)-mediated vasodilation of pial arterioles in rats. J Hypertens 2011;29: 1392-1399.

64. Oberleithner H, Callies C, Kusche-Vihrog K, et al. Potassium softens vascular endothelium and increases nitric oxide release. Proc Natl Acad Sci U S A 2009;106:2829-2834.

65. Feis J, Oberleithner H, Kusche-Vihrog K. Menage a trois: Aldosterone, sodium and nitric oxide in vascular endothelium. Biochim Biophys Acta 2010;1802:1193-1202.

66. Yang Q, Liu T, Kuklina EV, et al. Sodium and potassium intake and mortality among US adults: Prospective data from the third National Health and Nutrition Examination Survey. Arch Int Med 2011;171:1183-1191.

67. Houston MC, Harper KJ. Potassium, magnesium, and calcium: Their role in both the cause and treatment of hypertension. J Clin Hypertens 2008;10:3-11.

68. Perez V, Chang ET. Sodium-to-potassium ratio and blood pressure, hypertension, and related factors. Adv Nutr 2014;5:712-741.

69. Filippini T, Violi F, D'Amico R, Vinceti M. The effect of potassium supplementation on blood pressure in hypertensive subjects: A systematic review and metaanalysis. Int J Cardiol 2017;230:127-135.

70. Gu D, He J, Xigui W, et al. Effect of potassium supplementation on blood pressure in Chinese: A randomized, placebo-controlled trial. J Hypertens 2001;19:1325-1331.

71. D’Elia L, Barba G, Cappuccio FP, Strazzullo P. Potassium intake, stroke, and cardiovascular disease a meta-analysis of prospective studies. J Am Coll Cardiol 2011;57:1210-1219.

72. Poorolajal J, Zeraati F, Soltanian AR, et al. Oral potassium supplementation for management of essential hypertension: A meta-analysis of randomized controlled trials. PLoS One 2017;12:e0174967.

73. Houston MC. The importance of potassium in managing hypertension. Curr Hypertens Rep 2011;13:309-317.
74. Widman L, Wester PO, Stegmayr BG, Wirell MP. The dose dependent reduction in blood pressure through administration of magnesium: A double-blind placebo controlled cross-over trial. Am J Hypertens 1993;6: 41-45.

75. Laurant P, Touyz RM. Physiological and pathophysiological role of magnesium in the cardiovascular system: Implications in hypertension. $\mathbf{J}$ Hypertens 2000;18:1177-1191.

76. Zhang X, Li Y, Del Gobbo LC, et al. Effects of magnesium supplementation on blood pressure: A meta-analysis of randomized double-blind placebo-controlled trials. Hypertension 2016;68:324-333.

77. Kass L, Weekes J, Carpenter L. Effect of magnesium supplementation on blood pressure: A meta-analysis. Eur J Clin Nutr 2012;66:411-418.

78. Houston MC. The role of magnesium in hypertension and cardiovascular disease. J Clin Hyperten 2011;13:843-847.

79. Cormick G, Ciapponi A, Cafferata ML, Belizán JM. Calcium supplementation for prevention of primary hypertension. Cochrane Database Syst Rev 2015;6:CD010037.

80. Resnick LM. Calcium metabolism in hypertension and allied metabolic disorders. Diabetes Care 1991;14:505-520.

81. Garcia Zozaya JL, Padilla Viloria M. Alterations of calcium, magnesium, and zinc in essential hypertension: Their relation to the renin-angiotensinaldosterone system. Invest Clin 1997;38:27-40.

82. Hofmeyr GJ, Lawrie TA, Atallah AN, Duley L. Calcium supplementation during pregnancy for preventing hypertensive disorders and related problems. Cochrane Database Syst Rev 2010;8:CD001059.

83. Shahbaz AU, Sun Y, Bhattacharya SK, et al. Fibrosis in hypertensive heart disease: Molecular pathways and cardioprotective stratgies. J Hypetens 2010;28:S25-S32.

84. Bergomi M, Rovesti S, Vinceti M, et al. Zinc and copper status and blood pressure. J Trace Elem Med Biol 1997;11:166-169.

85. Stamler J, Elliott $\mathrm{P}$, Kesteloot $\mathrm{H}$, et al. Inverse relation of dietary protein markers with blood pressure. Findings for 10,020 men and women in the INTERSALT Study. INTERSALT Cooperative Research Group. INTERnational study of SALT and blood pressure. Circulation 1996;94:1629-1634.

86. Altorf-van der Kuil W, Engberink MF, Brink EJ, et al. Dietary protein and blood pressure: A systematic review. PLoS One 2010;5;e12102-e12117.

87. Jenkins, DJ, Kendall CW, Faulkner DA, et al. Long-term effects of a plant-based dietary portfolio of cholesterol-lowering foods on blood pressure. Eur J Clin Nutr 2008;62:781-788.

88. Rebholz CM, Friedman EE, Powers LJ, et al. Dietary protein intake and blood pressure: A meta-analysis of randomized controlled trials. Am J Epidemiol 2012;176:S27-S43.

89. He J, Wofford MR, Reynolds K, et al. Effect of dietary protein supplementation on blood pressure: A randomized controlled trial. Circulation 2011; $124 ; 589-595$.

90. FitzGerald RJ, Murray BA, Walsh DJ. Hypotensive peptides from milk proteins. J Nutr 2004:134:980S-988S.

91. Pins JJ, Keenan JM. Effects of whey peptides on cardiovascular disease risk factors. J Clin Hypertens 2006;8:775-782.

92. Aihara K, Kajimoto O, Takahashi R, Nakamura Y. Effect of powdered fermented milk with Lactobacillus helveticus on subjects with highnormal blood pressure or mild hypertension. J Am Coll Nutr 2005;24: $257-265$

93. Gemino FW, Neutel J, Nonaka M, Hendler SS. The impact of lactotripeptides on blood pressure response in stage 1 and stage 2 hypertensives. J Clin Hypertens 2010;12:153-159.

94. Geleijnse JM, Engberink MF. Lactopeptides and human blood pressure. Curr Opin Lipidol 2010;21:58-63.

95. Pins J, Keenan J. The antihypertensive effects of a hydrolyzed whey protein supplement. Cardiovasc Drugs Ther 2002;16:68. 
96. Zhu CF, Li GZ, Peng HB, et al. Therapeutic effects of marine collagen peptides on Chinese patients with type 2 diabetes mellitus and primary hypertension. Am J Med Sci 2010;340:360-366.

97. De Leo F, Panarese S, Gallerani R, Ceci LR. Angiotensin converting enzyme (ACE) inhibitory peptides: Production and implementation of functional food. Curr Pharm Des 2009;15:3622-3643.

98. Lordan S, Ross P, Stanton C. Marine Bioactives as functional food ingredients: Potential to reduce the incidence of chronic disease. Mar Drugs 2011;9:1056-1100.

99. Kawasaki T, Seki E, Osajima K, et al. Antihypertensive effect of valyltyrosine, a short chain peptide derived from sardine muscle hydrolyzate, on mild hypertensive subjects. J Hum Hypertens 2000;14:519-523.

100. Kawasaki T, Jun CJ, Fukushima Y, Seki E. [Antihypertensive effect and safety evaluation of vegetable drink with peptides derived from sardine protein hydrolysates on mild hypertensive, high-normal and normal blood pressure subjects]. Fukuoka Igaku Zasshi 2002;93:208-218.

101. Yang G, Shu XO, Jin F, et al. Longitudinal study of soy food intake and blood pressure among middle-aged and elderly Chinese women. Am J Clin Nutr 2005;81:1012-1017.

102. Teede HJ, Giannopoulos D, Dalais FS, et al. Randomised, controlled, cross-over trial of soy protein with isoflavones on blood pressure and arterial function in hypertensive patients. J Am Coll Nutr 2006;25:533-540.

103. Welty FK, Lee KS, Lew NS, Zhou JR. Effect of soy nuts on blood pressure and lipid levels in hypertensive, prehypertensive and normotensive postmenopausal women. Arch Inter Med 2007;167:1060-1067.

104. Mohanty DP, Mohapatra S, Misra S, et al. Milk derived bioactive peptides and their impact on human health. A review. J Biol Sci 2016;23:577-583.

105. Nasca MM, Zhou JR, Welty FK. Effect of soy nuts on adhesion molecules and markers of inflammation in hypertensive and normotensive postmenopausal women. Am J Cardiol 2008;102:84-86.

106. He J, Gu D, Wu X, et al. Effect of soybean protein on blood pressue: A randomized, controlled trial. Ann Intern Med 2005:143:1-9.

107. Hasler CM, Kundrat S, Wool D. Functional foods and cardiovascular disease. Curr Atheroscler Rep 2000;2:467-475.

108. Liu XX, Li SH, Chen JZ, et al. Effect of soy isoflavones on blood pressure: A meta-analysis of randomized controlled trials. Nutr Metab Cardiovasc Dis 2012; 22:463-470.

109. Begg DP, Sinclari AJ, Stahl LA, et al. Dietary proteins level interacts with omega-3 polyunsaturated fatty acid deficiency to induce hypertension. Am J Hyperten 2010;23:125-128

110. Fekete ÁA, Giromini C, Chatzidiakou Y, et al. Whey protein lowers blood pressure and improves endothelial function and lipid biomarkers in adults with prehypertension and mild hypertension: Results from the chronic Whey2Go randomized controlled trial. Am J Clin Nutr 2016;104:1534-1544.

111. Dong JY, Szeto IM, Makinen K, et al. Effect of probiotic fermented milk on blood pressure: A meta-analysis of randomised controlled trials. Br J Nutr 2013;110:1188-1194.

112. Cicero AF, Gerocarni B, Laghi L, Borghi C. Blood pressure lowering effect of lactotripeptides assumed as functional foods: A meta-analysis of current available clinical trials. J Hum Hypertens 2011;25:425-436.

113. Cicero AF, Aubin F, Azais-Braesco V, Borghi C. Do the lactotripeptides isoleucine-proline-proline and valine-proline-proline reduce systolic blood pressure in European subjects? A meta-analysis of randomized controlled trials. Am J Hypertens 2013;26:442-449.

114. Cicero AF, Rosticci M, Gerocarni B, et al. Lactotripeptides effect on office and 24-h ambulatory blood pressure, blood pressure stress response, pulse wave velocity and cardiac output in patients with high-normal blood pressure or first-degree hypertension: A randomized double-blind clinical trial. Hypertens Res 2011;34:1035-1040.

115. Morris MC. Dietary fats and blood pressure. J Cardiovasc Risk 1994;1: 21-30.
116. Siani A, Pagano E, Iacone $R$, et al. Blood pressure and metabolic changes during dietary L-arginine supplementation in humans. Am J Hypertens 2000;13:547-551.

117. Vallance P, Leone A, Calver A, et al. Endogenous dimethyl-arginine as an inhibitor of nitric oxide synthesis. J Cardiovasc Pharmacol 1992;20: S60-S62.

118. Ruiz-Hurtado G, Delgado C. Nitric oxide pathway in hypertrophied heart: New therapeutic uses of nitric oxide donors. J Hypertens 2010;28:56-61.

119. Sonmez A, Celebi G, Erdem G, et al. Plasma apelin and ADMA levels in patients with essential hypertension. Clin Exp Hypertens 2010;32:179-183.

120. Michell DL, Andrews KL, Chin-Dusting JP. Endothelial dysfunction in hypertension: The role of arginase. Front Biosci (Schol Ed) 2011;3:946-960.

121. Rajapakse NW, Mattson DL. Role of L-arginine in nitric oxide production in health and hypertension. Clin Exp Pharmacol Physiol 2009;36: 249-255.

122. Tsioufis C, Dimitriadis K, Andrikou E, et al. ADMA, C-reactive protein and albuminuria in untreated essential hypertension: A cross-sectional study. Am J Kidney Dis 2010;55:1050-1059.

123. Facchinetti F, Saade GR, Neri I, et al. L-Arginine supplementation in patients with gestational hypertension: A pilot study. Hypertens Pregnancy 2007;26:121-130.

124. Neri I, Monari F, Sqarbi L, et al. L-Arginine supplementation in women with chronic hypertension: Impact on blood pressure and maternal and neonatal complications. J Matern Fetal Neonatal Med 2010;23:1456-1460.

125. Martina V, Masha A, Gigliardi VR, et al. Long-term N-acetylcysteine and L-arginine administration reduces endothelial activation and systolic blood pressure in hypertensive patients with type 2 diabetes. Diabetes Care 2008;31:940-944

126. Ast J, Jablecka A, Bogdanski I, et al. Evaluation of the antihypertensive effect of L-arginine supplementation in patients with mild hypertension assessed with ambulatory blood pressure monitoring. Med Sci Monit 2010;16: 266-271.

127. Schulman SP, Becker LC, Kass DA, et al. L arginine therapy in acute myocardial infraction: The vascular interaction with age in myocardial infarction (VINTAGE MI) randomized clinical trial. JAMA 2006;295:58-64.

128. Dong JY, Qin JQ, Zhang ZL, et al. Effect of oral L-arginine supplementation on blood pressure: A meta-analysis of randomized, double-blind, placebo-controlled trials. Am Heart J 2011;162:959-965.

129. Huxtable RJ. Physiologic actions of taurine. Physiol Rev 1992;72: $101-163$.

130. Fujita $\mathrm{T}$, Ando $\mathrm{K}$, Noda $\mathrm{H}$, et al. Effects of increased adrenomedullary activity and taurine in young patients with borderline hypertension. Circulation 1987;75:525-532.

131. Huxtable RJ, Sebring LA. Cardiovascular actions of taurine. Prog Clin Biol Res 1983;125:5-37.

132. Tanabe $\mathrm{Y}$, Urata $\mathrm{H}$, Kiyonaga $\mathrm{A}$, et al. Changes in serum concentrations of taurine and other amino acids in clinical antihypertensive exercise therapy. Clin Exp Hypertens 1989;11:149-165.

133. Yamori $Y$, Taguchi T, Mori H, Mori M. Low cardiovascular risks in the middle age males and females excreting greater 24-hour urinary taurine and magnesium in 41 WHO-CARDIAC study populations in the world. J Biomed Sci 2010;17:s21s26.

134. Wang B, Li Y, Sun F, et al. Taurine supplementation lowers blood pressure and improves vascular function in prehypertension: Randomized, double-blind, placebo-controlled study. Hypertension 2016;67:541-549.

135. Houston MC. Combination nutraceutical supplement lowers blood pressure in hypertensive individuals. Integr Med 2013;12:22-28.

136. Sun $\mathrm{Q}$, Wang B, Li Y, et al. Taurine supplementation lowers blood pressure and improves vascular function in prehypertension: Randomized, double-blind, placebo-controlled study. Hypertension 2016;67:541-549. 
137. Mori TA, Bao DQ, Burke V, et al. Docosahexaenoic acid but not eicosapentaenoic acid lowers ambulatory blood pressure and heart rate in humans. Hypertension 1999;34:253-260.

138. Bønaa KH, Bjerve KS, Straume B, et al. Effect of eicosapentaenoic and docosahexanoic acids on blood pressure in hypertension: A populationbased intervention trial from the Tromsø Study. N Engl J Med 1990;322: 795-801.

139. Mori TA, Burke V, Puddey I, Irish A. The effects of omega 3 fatty acids and coenzyme Q 10 on blood pressure and heart rate in chronic kidney disease: A randomized controlled trial. J Hypertens 2009;27:1863-1872.

140. Ueshima H, Stamler J, Elliot B, Brown CQ. Food omega 3 fatty acid intake of individuals (total, linolenic acid, long chain) and their blood pressure: INTERMAP study. Hypertension 2007;50:313-319.

141. Mon TA. Omega 3 fatty acids and hypertension in humans. Clin Exp Pharmacol Physio 2006;33:842-846.

142. Liu JC, Conkin SM, Manuch SB, et al. Long-chain omega-3 fatty acids and blood pressure. Am J Hypertens 2011;24:1121-1126.

143. Engler MM, Schambelan M, Engler MB, Goodfriend TL. Effects of dietary gamma-linolenic acid on blood pressure and adrenal angiotensin receptors in hypertensive rats. Proc Soc Exp Biol Med 1998;218: 234-237.

144. Sagara M, Njelekela M, Teramoto T, et al. Effects of docoahexaenoic acid supplementation on blood pressure, heart rate, and serum lipid in Scottish men with hypertension and hypercholesterolemia. Int J Hypertens 2011;8: 8091-8098.

145. Colussi G, Catena C, Novello M, et al. Impact of omega-3 polyunsaturated fatty acids on vascular function and blood pressure: Relevance for cardiovascular outcomes. Nutr Metab Cardiovasc Dis 2017;27:191-200.

146. Miller PE, Van Elswyk M, Alexander DD. Long-chain omega-3 fatty acids eicosapentaenoic acid and docosahexaenoic acid and blood pressure: A meta-analysis of randomized controlled trials. Am J Hypertens 2014;27: 885-896.

147. Pase MP, Grima NA, Sarris J. Do long-chain n-3 fatty acids reduce arterial stiffness? A meta-analysis of randomised controlled trials. Br J Nutr 2011;106:974-980.

148. Cicero AF, Ertek S, Borghi C. Omega-3 polyunsaturated fatty acids: Their potential role in blood pressure prevention and management. Curr Vasc Pharmacol 2009;7:330-337.

149. Minihane AM, Armah CK, Miles EA, et al. Consumption of fish oil providing amounts of eicosapentaenoic acid and docosahexaenoic acid that can be obtained from the diet reduces blood pressure in adults with systolic hypertension: A retrospective analysis. J Nutr 2016;146:516-523.

150. Rodriguez-Leyva $\mathrm{D}$, Weighell $\mathrm{W}$, Edel AL, et al. Potent antihypertensive action of dietary flaxseed in hypertensive patients. Hypertension 2013; 62:1081-1089.

151. Saravanan P, Davidson NC, Schmidt EB, Calder PC. Cardiovascular effects of marine omega-3 fatty acids. Lancet 2010;376:540-550.

152. Alexander DD, Miller PE, Van Elswyk ME, et al. A meta-analysis of randomized controlled trials and prospective cohort studies of eicosapentaenoic and docosahexaenoic long-chain omega-3 fatty acids and coronary heart disease risk. Mayo Clin Proc 2017;92:15-29.

153. Ferrara LA, RaimondiS, d'Episcopa I. Olive oil and reduced need for antihypertensive medications. Arch Intern Med 2000;160:837-842.

154. Perona JS, Canizares J, Montero E, et al. Virgin olive oil reduces blood pressure in hypertensive elderly patients. Clin Nutr 2004;23:1113-1121.

155. Perona JS, Montero E, Sanchez-Dominquez JM, et al. Evaluation of the effect of dietary virgin olive oil on blood pressure and lipid composition of serum and low-density lipoprotein in elderly type 2 subjects. J Agric Food Chem 2009;57:11427-11433

156. Lopez-Miranda J, Perez-Jimenez F, Ros E, et al. Olive oil and health: Summary of the II international conference on olive oil and health consensus report, Jaen and Cordoba (Spain) 2008. Nutr Metab Cardiovasc Dis 2010;20 284-294.

157. Thomsen C, Rasmussen OW, Hansen KW, et al. Comparison of the effects on the diurnal blood pressure, glucose, and lipid levels of a diet rich in monounsaturated fatty acids with a diet rich in polyunsaturated fatty acids in type 2 diabetic subjects. Diabet Med 1995;12:600-606.

158. Sofi F, Abbate R, Gensini GF, Casini A. Accruing evidence on benefits of adherence to the Mediterranean diet on health: An updated systematic review and meta-analysis. Am J Clin Nutr 2010;92:1189-1196.

159. Estruch R, Ros E, Salas-Salvadó J, et al. Primary prevention of cardiovascular disease with a Mediterranean diet. N Engl J Med 2013;368:12791290

160. Nadtochiy SM, Redman EK. Mediterranean diet and cardioprotection: The role of nitrite, polyunsaturated fatty acids, and polyphenols. Nutrition 2011;27:733-744.

161. Salas-Salvadó J, Bulló M, Estruch R, et al. Prevention of diabetes with Mediterranean diets: A subgroup analysis of a randomized trial. Ann Intern Med 2014;160:1-10.

162. Lopez S, Bermudez B, Montserrat-de la Paz S, et al. Virgin olive oil and hypertension. Curr Vasc Pharmacol 2016;14:323-329.

163. Martín-Peláez S, Castañer O, Konstantinidou V, et al. Effect of olive oil phenolic compounds on the expression of blood pressure-related genes in healthy individuals. Eur J Nutr 2017;56:663-670

164. Storniolo CE, Casillas R, Bulló M, et al. A Mediterranean diet supplemented with extra virgin olive oil or nuts improves endothelial markers involved in blood pressure control in hypertensive women. Eur J Nutr 2017; 56:89-97.

165. Hohmann $\mathrm{CD}$, Cramer $\mathrm{H}$, Michalsen A, et al. Effects of high phenolic olive oil on cardiovascular risk factors: A systematic review and metaanalysis. Phytomedicine 2015;22:631-640.

166. Doménech $M$, Roman $P$, Lapetra J, et al. Mediterranean diet reduces 24-hour ambulatory blood pressure, blood glucose, and lipids: One-year randomized, clinical trial. Hypertension 2014;64:69-76.

167. Lockyer S, Rowland I, Spencer JP, et al. Impact of phenolic-rich olive leaf extract on blood pressure, plasma lipids and inflammatory markers: A randomized controlled trial. Eur J Nutr 2017;56:1421-1432.

168. Cabrera-Vique C, Navarro-Alarcón M, Rodríguez Martínez C, FonolláJoya J. Hypertensive effect of an extract of bioactive compounds olive leaves preliminary clinical study. Nutr Hosp 2015;32:242-249.

169. Susalit E, Agus N, Effendi I, et al. Olive (Olea europaea) leaf extract effective in patients with stage-1 hypertension: Comparison with Captopril. Phytomedicine 2011;18:251-258.

170. Flynn M, Wang S. Olive oil as medicine: The effect on blood pressure. The Report of UCD Olive Center, December 2015.

171. Psaltopoulou T, Naska A, Orfanos $P$, et al. Olive oil, the Mediterranean diet, and arterial blood pressure: The Greek European Prospective Investigation into Cancer and Nutrition (EPIC) study. Am J Clin Nutr 2004;80: 1012-1018.

172. Toledo E, Hu FB, Estruch R, et al. Effect of the Mediterranean diet on blood pressure in the PREDIMED trial: Results from a randomized controlled trial. BMC Med 2013;11:207.

173. Perrinjaquet-Moccetti T, Busjahn A, Schmidlin C, et al. Food supplementation with an olive (Olea uropaea L.) leaf extract reduces blood pressure in borderline hypertensive monozygotic twins. Phytother Res 2008;22:1239-1242.

174. Davis CR, Hodgson JM, Woodman R, et al. A Mediterranean diet lowers blood pressure and improves endothelial function: Results from the MedLey randomized intervention trial. Am J Clin Nutr 2017;105:1305-1313.

175. Miura K, Stamler J, Brown IJ, et al. INTERMAP Research Group Relationship of dietary monounsaturated fatty acids to blood pressure: The International Study of Macro/Micronutrients and Blood Pressure. J Hypertens 2013;31:1144-1150 
176. Perrinjaquet-Moccetti $\mathrm{T}$, Busjahn A, Schmidlin C, et al. Food supplementation with an olive (Olea europaea L.) leaf extract reduces blood pressure in borderline hypertensive monozygotic twins. Phytother Res 2008;22:12391242.

177. Sherman DL, Keaney JF, Biegelsen ES, et al. Pharmacological concentrations of ascorbic acid are required for the beneficial effect on endothelial vasomotor function in hypertension. Hypertension 2000;35:936-941.

178. Ness AR, Khaw K-T, Bingham S, Day NE. Vitamin C status and blood pressure. J Hypertens 1996;14:503-508.

179. Duffy SJ, Bokce N, Holbrook M, et al. Treatment of hypertension with ascorbic acid. Lancet 1999;354:2048-2049.

180. Enstrom JE, Kanim LE, Klein M. Vitamin C intake and mortality among a sample of the United States population. Epidemiology 1992;3:194-202.

181. Block G, Jensen, CD, Norkus EP, et al. Vitamin C in plasma is inversely related to blood pressure and change in blood pressure during the previous year in young black and white women. Nut J 2008;17:35-46.

182. Hatzitolios A, Iliadis F, KatsikiN, Baltatzi M. Is the antihypertensive effet of dietary supplements via aldehydes reduction evidence based: A systemic review. Clin Exp Hypertens 2008:30;628-639.

183. Mahajan AS, Babbar R, Kansai N, et al. Antihypertensive and antioxidant action of amlodipine and vitamin $\mathrm{C}$ in patients of essential hypertension. J CLin Biochem Nutr 2007;402;141-147.

184. Ledlerc PC, Proulx, CD, Arquin G, Belanger S. Ascorbic acid decreases the binding affinity of the AT1 receptor for angiotensin II. Am J Hypertens 2008:21:67-71.

185. Plantinga Y, Ghiadone L, Magagna A, Biannarelli C. Supplementation with vitamins $\mathrm{C}$ and $\mathrm{E}$ improves arterial stiffness and endothelial function in essential hypertensive patients. Am J Hypertens 2007;20:392-397.

186. Sato K, Dohi Y, Kojima M, Miyagawa K. Effects of ascorbic acid on ambulatory blood pressure in elderly patients with refractory hypertension. Arzneimittelforschung 2006;56:535-540.

187. Block G, Mangels AR, Norkus EP, et al. Ascorbic acid status and subsequent diastolic and systolic blood pressure. Hypertension 2001;37:261-267.

188. McRae MP. Is Vitamin C an effective antihypertensive supplement? A review and analysis of the literature. J Chiropr Med 2006;5:60-64.

189. Simon JA. Vitamin C and cardiovascular disease: A review. J Am Coll Nutr 1992;11:107-125.

190. Ness AR, Chee D, Elliott P. Vitamin $C$ and blood pressure-An overview. J Hum Hypertens 1997;11:343-350.

191. Trout DL. Vitamin C and cardiovascular risk factors. Am J Clin Nutr 1991;53:322S-325S.

192. Ried K, Travica N, Sali A. The acute effect of high-dose intravenous vitamin $\mathrm{C}$ and other nutrients on blood pressure: A cohort study. Blood Press Monit 2016;21:160-167.

193. Buijsse B, Jacobs DR Jr, Steffen LM, et al. Plasma ascorbic acid, a priori diet quality score, and incident hypertension: A prospective cohort study. PLoS One 2015;10:e0144920.
194. Hajjar IM, George V, Sasse EA, Kochar MS. A randomized, doubleblind, controlled trial of vitamin $\mathrm{C}$ in the management of hypertension and lipids. Am J Ther 2002;9:289-293.

195. National Center for Health Statistics, Fulwood R, Johnson CL, Bryner JD. Hematological and nutritional biochemistry reference data for persons 6 months-74 years of age: United States, 1976-80. Washington, DC; US Public Health Service; 1982 Vital and Health Statistics series 11, No. 232, DHHS publication no. (PHS) 83-1682.

196. McCartney DM, Byrne DG, Turner MJ. Dietary contributors to hypertension in adults reviewed. Ir J Med Sci 2015;184:81-90.

197. Enstrom JE, Kanim LE, Klein M. Vitamin C intake and mortality among a sample of the United States population. Epidemiology 1992;3:194202.

198. Block G, Jensen CD, Norkus EP, et al. Vitamin C in plasma is inversely related to blood pressure and change in blood pressure during the previous year in young black and white women. Nutr J 2008;17:35-46.

199. Juraschek SP, Guallar E, Appel LJ, Miller ER 3rd. Effects of vitamin C supplementation on blood pressure: A meta-analysis of randomized controlled trials. Am J Clin Nutr 2012;95:1079-1088.

200. Ward NC, Wu JH, Clarke MW, Puddy IB. The effect of vitamin E on blood pressure in individuals with type 2 diabetes: A randomized, doubleblind, placebo-controlled trial. J Hypertens 2007;25:227-234.

201. Murray ED, Wechter WJ, Kantoci D, et al. Endogenous natriuretic factors 7: Biospecificity of a natriuretic gamma-tocopherol metabolite LLU alpha. J Pharmacol Exp Ther 1997;282:657-662.

202. Gray B, Swick J, Ronnenberg AG. Vitamin E and adiponectin: Proposed mechanism for vitamin E-induced improvement in insulin sensitivity. Nutr Rev 2011;69:155-161.

203. Kuwabara A, Nakade M, Tamai $H$, et al. The association between vitamin E intake and hypertension: Results from the re-analysis of the National Health and Nutrition Survey. J Nutr Sci Vitaminol (Tokyo) 2014;60:239-245.

204. Hodgson JM, Croft KD, Woodman RJ, et al. Effects of vitamin E, vitamin $\mathrm{C}$ and polyphenols on the rate of blood pressure variation: Results of two randomised controlled trials. Br J Nutr 2014;112:1551-1561.

205. Houston MC. Vascular Biology in Clinical Practice. Philadelphia, PA: Hanley and Belfus, 2000.

206. Houston M. Handbook of Hypertension. Oxford UK: Wiley Blackwell, 2009.

Mark C. Houston, MD, MS, MSc, FACP, FAHA, FASH, FACN, FAARM, DABC, is an Associate Clinical Professor of Medicine at Vanderbilt University School of Medicine in Nashville, Tennessee, and Director of the Hypertension Institute and Vascular Biology, also in Nashville, Tennessee.

To order reprints of this article, contact the publisher at (914) 740-2100. 